\title{
Review
}

\section{Implications of reef ecosystem change for the stability and maintenance of coral reef islands}

\section{Running title: Ecosystem change and reef island stability}

Chris T. Perry ${ }^{1}$, Paul S. Kench ${ }^{2}$, Scott G. Smithers ${ }^{3}$, Bernhard Riegl ${ }^{4}$, Hiroya Yamano ${ }^{5}$, Michael J. O'Leary ${ }^{6}$

${ }^{1}$ School of Science and the Environment, Manchester Metropolitan University, Chester Street, Manchester M1 5GD. U.K. ${ }^{2}$ School of Environment, The University of Auckland, New Zealand. ${ }^{3}$ School of Earth and Environmental Science, James Cook University, Townsville, Qld 4811, Australia. ${ }^{4}$ National Coral Reef Institute, Nova Southeastern University, 8000 N. Ocean Drive Dania, FL 33004, USA. ${ }^{5}$ Center for Environmental Biology and Ecosystem Studies, National Institute for Environmental Studies, 16-2 Onogawa, Tsukuba, Ibaraki 305-8506, Japan. ${ }^{6}$ School of Arts and Sciences, The University of Notre Dame Australia Fremantle, Western Australia 6959, Australia

Corresponding author:

C.T. Perry, School of Science and the Environment, Manchester Metropolitan University, John Dalton Building, Manchester M1 5RD.

E-mail: c.t.perry@mmu.ac.uk Tel: +44(0)1612476210

Keywords: Reef islands, island vulnerability, reef sediments, ecological change, climate change 


\section{Abstract.}

Coral reef islands are amongst the most vulnerable environments on Earth to climate change because they are low lying and largely constructed from unconsolidated sediments that can be readily reworked by waves and currents. These sediments derive entirely from surrounding coral reef and reef flat environments and are thus highly sensitive to ecological transitions that may modify reef community composition and productivity. How such modifications driven by anthropogenic disturbances and on-going and projected climatic and environmental change - will impact reef island sediment supply and geomorphic stability remains a critical but poorly resolved question. Here we review the unique ecological - geomorphological linkages that underpin this question and, using different scenarios of environmental change for which reef sediment production responses can be projected, explore the likely resilience of different island types. In general, sand-dominated islands are likely to be less resilient than those dominated by rubble grade material. However, because different islands typically have different dominant sediment constituents (usually either coral, benthic foraminifera or Halimeda) and because these respond differently to individual ecological disturbances, island resilience is likely to be highly variable. Islands composed of coral sands are likely to undergo major morphological change under most near-future ecological change scenarios, whilst those dominated by Halimeda may be more resilient. Islands composed predominantly of benthic foraminifera (a common state through the Pacific region) are likely to exhibit varying degrees of resilience depending upon the precise combination of ecological disturbances faced. The study demonstrates the critical need for further research bridging the ecological-geomorphological divide in order to understand: 1) sediment production responses to different ecological and environmental change scenarios; and 2) dependant landform vulnerability. 


\section{Introduction}

'Oceanic states composed of atolls, such as Kiribati in the Pacific and the Republic of Maldives in the Indian Ocean, face severe consequences as a result of sea level rise. They can be wiped off the globe literally if sea levels continue to rise at their current rates' (Khan et al. 2002)

Reef islands are low-lying (typically $<5 \mathrm{~m}$ above mean sea level) accumulations of biogenically-derived sediments (McLean \& Woodroffe, 1994). In areas of low storm frequency these landforms are typically constructed of unconsolidated, reef-derived sands, whilst in areas of higher storm frequency they are typically shingle and gravel dominated (Kench et al. 2009): these are termed, respectively, sand cays and motu (Stoddart \& Steers 1977). Reef islands are highly significant for a range of socio-economic and ecological reasons: they form the only habitable land in regions such as the Maldives (Indian Ocean), Tuvalu, Kiribati and the Marshall Islands (Pacific), and Torres Strait; provide key habitats for a range of threatened species such as green turtles (Fuentes et al. 2011), and support endemic populations of terrestrial amphibians, mammals and reptiles (see Roy \& Connell 1991). Reef and atoll islands have, however, long been considered extremely vulnerable to future sealevel rise and to the effects of environmental change (discussed in Woodroffe 2008), a view endorsed in the IPCC $4^{\text {th }}$ Assessment (Parry et al. 2007). Such vulnerability is linked in part to their limited size, but also to the general vulnerability of the populations and associated human infrastructure to physical disturbance events (e.g., cyclones, storm surges, tsunami Roy \& Connell 1991; Kench et al. 2006). Climate change raises an additional spectre of threat: the impacts of recent and projected sea-level rise on islands has been a topic of wide debate (see: Mörner et al. 2004; Kench et al. 2005; Church et al. 2006), but poses a direct threat through potential land submergence and/or shoreline erosion, and increased salt water 
intrusion into the fresh water lens of islands that threatens agricultural and water resources (Roy \& Connell 1991; Woodroffe 2005; Yamano et al. 2007). Climate change related shifts in sea-surface temperatures, ocean chemistry and storm frequency may also directly impact the coral reefs that play a critical role in island development.

Underpinning such views of vulnerability is a widespread assumption that islands exist as geomorphologically passive entities that will simply inundate and erode incrementally as sea levels rise (Dickinson 2009). However, such assertions fail to acknowledge that island construction and future landform trajectories are intricately linked to the biology of the surrounding coral reefs and reef flats, and specifically to the ecological processes that mediate some of the key sediment production pathways. In this context, surrounding reefs act as biological factories that yield a (continuous) supply of sediment that is selectively available, under appropriate wave and current regimes, to build and maintain islands (Woodroffe et al. 2007; Fig. 1). This ecomorphodynamic understanding indicates that shifts in ecological processes, that can subsequently drive changes in sediment production, might be a more critical control on island change than sea level (Kench \& Cowell 2003). The importance of this ecologically-modulated sediment supply on the future sustainability of reef and low-lying island landforms remains, however, poorly resolved.

From the perspective of predicting future reef island stability there is thus a specific need to improve understanding of the ecological-geomorphological linkages that exist in these systems and, in particular, how reef ecological change impacts initially upon the biology of the reef habitats and, subsequently, on the biological sediment factory. The nature and magnitude of on-going and projected ecological change in reef ecosystems, linked to overfishing, increased pollution, coral disease, coral bleaching and impending ocean 
acidification has been widely discussed (Jackson et al. 2001; Pandolfi et al. 2003, HoeghGuldberg et al. 2007). Only recently, however, have explicit links been made between such ecological changes and the physical components of these environments: changes in reef geomorphology (Lewis 2002; Alvarez-Filip et al. 2011), carbonate production rates (Perry et al. 2008) and sediment production (Perry 1996; Cockey et al. 1996; Lidz \& Hallock 2000; Collen \& Garton 2004; Chazottes et al. 2008). In one sense these links are intuitive because coral reef sediments derive primarily from calcifying reef organisms, i.e., the ecological components of the system. Thus the 'health' and functionality of the biological system is a critical issue. However, in contrast to the often direct impacts of environmental change on benthic reef ecology, caused by changed mortality potential, the degree of connectivity that exists between ecology (and ecological change) and sediment production is more variable. In some cases, there is a strong (but variable) link between ecological change and sediment generation. For example, the abundance and size of parrotfish strongly controls the rates at which they erode coral substrate (and produce sediment) (Bruggemann et al. 1996). Thus loss of larger individuals of parrotfish (which are often preferentially removed through overfishing) will thus have a particularly significant and immediate effect on this source of grazing-derived coral sediment production. In other cases, responses may be more complex and temporally disconnected, such as those linked to coral bleaching. Resultant sediment yields, caused by biological and physical erosion of the newly dead coral substrate, may take many years to manifest, but may, at least temporarily, exceed that of the unbleached reef.

Since reef islands are dependent upon this ecologically-driven sediment supply for their construction and maintenance (Kench et al. 2009), the ecological state, productivity, and spatial and temporal dynamics of the biological sediment factory is thus of fundamental importance. Furthermore, actual sediment supply to islands is usually a highly selective 
process determined by sediment type, grade (size), shape and density, which control sediment hydrodynamic behaviour and thus transport potential (Braithwaite 1973; Kench 1997). Thus many beaches and islands are composed of a relatively restricted suite of grain types and grain size fractions (Folk \& Robles 1964; Yamano et al. 2000; Dawson \& Smithers 2010; McKoy et al. 2010).

Here we review the hierarchy of geomorphological and ecological processes that have controlled the timing, form and composition of reef islands over geological timescales (since $\sim 6,000$ years ago), and consider their likely resilience, as a function of biologically-controlled sediment supply, in relation to projected environmental changes over ecological timescales (over the next century). Specifically, we: 1) provide a brief review of the role of Holocene sea-level - reef growth interactions as a fundamental control on reef island initiation and growth over longer (centennial to millennial timescales), and which provides a framework within which to consider the contemporary reef ecological and sedimentological processes influencing reef island morphological change; 2) consider the links that exist between reef ecology and island sediment constituents in terms of the types and grades of sediment deriving from the biological production zones around islands and which are then selectively made available for island-building; 3) discuss the impacts of different natural and anthropogenic drivers of reef ecological change that subsequently can impact upon reef sediment production and thus sediment supply to islands; and 4) consider the viability of modelling island ecological-sedimentological linkages as driven by ecological state changes. We conclude with specific modelled scenarios of ecological and environmental change and consider the likely implications for the resilience of different island types. 


\section{Reef island development: the role of sea-level - reef growth interactions and models} of island evolution

\subsection{Reef island initiation and growth: long-term controls and timescales of development}

A fundamental control on the initiation and development of reef islands has been the interaction between Holocene reef growth, the rate of lagoon infilling and the rate of sealevel rise, in the sense that the development of, at least near-emergent (and thus sea-level constrained), reef flats or infilled lagoons has been a necessary pre-requisite for the subaerial accumulation of reef sediment and/or rubble. Thus past rates of sea-level rise, stillstand and/or regression, set against local reef growth rates, have played a key role in the timing of Holocene reef island initiation and growth. In a number of cases island initiation seems to have occurred when, or shortly after, the underlying reefs reached sea level and reef platforms/flats were established. Often this has occurred under slightly higher than present sea levels. Examples include the reef islands described from Kiribati in the Pacific (Woodroffe \& Morrison 2001) and Warraber, Yam and Hammond Islands in Torres Strait (Woodroffe et al. 2000) (Fig. 2A), and from Cocos in the Eastern Indian Ocean (Woodroffe et al. 1999) (Fig. 2B). Within the constraints of existing growth chronological studies, there is good evidence that these islands have expanded in size through the subsequent period of small scale ( 0.5 -1 m) sea-level fall - although growth modes have undoubtedly varied between islands and are unlikely to have been temporally uniform.

Views about whether post-highstand sea-level fall itself is necessary to drive island initiation vary, some authors arguing in favour of this idea (e.g., Dickinson 2009), others suggesting it is not a pre-requisite (e.g., Woodroffe et al. 1999). Where islands have formed under conditions of relative sea-level fall, this has often been accompanied by changes not only in growth mode (and thus morphology), but also in the surrounding reef habitats. A function of 
these ecological changes has been a shift in sediment production regimes (see Yamano et al. 2001). However, more recent data from the Maldives indicates that some islands may have established through the very late stages of the Holocene transgression and highstand i.e., as sea-level was still in the final stages of rise (Kench et al. 2005) (Fig. 2C). The key implication of this being that highstand sea-level attainment and subsequent fall has not been an implicit pre-requisite for island initiation, a view supported by the occurrence of reef islands in the Caribbean and the development of new islands in areas of relatively stable sea level. Although island growth chronologies in the Caribbean are poorly constrained, reef islands have clearly established across the region where the late Holocene has been characterised by slow sea-level rise and where a mid-Holocene sea-level highstand did not occur (Fig. 2D).

\subsection{Modes and magnitudes of post-initiation island morphological change}

Once islands have initiated prevailing wave/current regimes, storm frequencies and sediment supply regimes interact to control styles of island morphological evolution. In this context, Woodroffe et al. (1999) and Woodroffe (2002) proposed a range of schematic morphological evolutionary models that are a function of these interactions (summarised in Fig. 3). Some of these models explain situations where islands have grown consistently over time either from a central point (the 'central core' scenario) or in a predominant direction (e.g., the 'oceanward' or 'lagoonward accretion' models) as a function of sediment being added to one side of an island or the other. In other cases, islands may evolve through sediment transfer, either as a function of sediment being stripped from one side of the island and moved to the other (the 'rollover' model), or through sediment being washed over the island (the 'washover' model). Finally, in some cases, islands may have been built in single events (perhaps as a product of a very high energy event) and undergone little obvious 
morphological change since, or conversely may be erosional remnants that have progressively reduced in size over time.

In a more expansive version of these models, Woodroffe et al. (1999) also considered the potential for temporal changes in island growth modes driven by changes in sediment supply and retention - models that have direct relevance for understanding island change under ongoing and projected environmental and ecological change scenarios as sediment supply pathways are interrupted. The most likely effect of any such changes would be phases of island destabilisation and shoreline change. However, an important cautionary note must be sounded at sites where apparent shoreline scarping is occurring, because recent datasets clearly show that a high degree of island shoreline morphological change can occur as a function of seasonal reversals in wave energy regimes (Kench \& Brander, 2006; Dawson \& Smithers, 2010). The net effect of these reversals is to move sediment alternately from one island flank to another, driving seasonal changes from net accretion to net erosion and back again. Similarly, longer temporal datasets have shown that whilst islands can often be relatively mobile on their reef platform surfaces, this does not necessarily equate to a loss of total island area or volume, just a repositioning of the island structure (Webb \& Kench 2010; Dawson \& Smithers, 2010).

\section{Interactions between reef ecology and island sediment supply: the role of the}

\section{biological sediment factory}

As discussed above, with some minor variations, a first order requirement for reef island initiation and accumulation is that the reef platform is close to or at sea level. An important second order control for reef island development is the supply of sediments from the reef flat and platform on which islands form. The sedimentary traits and rate of supply of these 
sediments is a key influence on island development and form, and ultimately on island resilience into the future. The characteristics of this 'biological sediment factory' and the potential for transfer of this sediment to islands are discussed below.

\subsection{Sediment production and reef ecology}

The strong ecological-sedimentary linkages that exist in reef environments arise from the fact that most sediment is derived either directly or indirectly from reef biota. Thus the composition and character of that biota (in terms of species presence and abundance) will strongly influence the types, size and rate of sediment produced. In essence, two main pathways of sediment production can be distinguished: (1) sediment sourced directly from the skeletal remains of various infaunal and epifaunal calcareous taxa (foraminifera, molluscs etc) that live in and on reef framework and sediment; and (2) sediment produced as a byproduct of the physical and biological erosion of the reef framework.

Shelly infaunal and epifaunal species such as molluscs, echinoids and foraminifera, which live on or within the reef framework and sediment are a major source of reef sediment, as are (locally) the various epiphytic species (e.g. crustose coralline algae, foraminifera) that colonise the blades of seagrasses and are released as sediment after death of the plant (Nelson \& Ginsburg 1986), and carbonate-secreting algae like Halimeda and Penicillus (Neumann and Land 1975). Distinct differences occur in the basic sedimentary properties (e.g., morphology) of these different bioclasts (biologically derived sediments) at their initial point of production. The size and form of these constituents will also vary as a function of reef community composition and productivity of the contributing taxa. For example, foraminifera test size in the sediment depends upon species: Peneroplis have discoidal tests typically $0.5-$ $2 \mathrm{~mm}$ in size; whereas spindle-shaped Quinqueloculina tests are usually $<0.5 \mathrm{~mm}$ in size 
(Fig. 4). In contrast, the calcareous green algae Halimeda initially disarticulate into individual segments $\sim 2-5 \mathrm{~mm}$ in size (Fig. 4).

Significant quantities of sediment are also produced by physical and biological erosion primarily of the coral-dominated fabric of the reef. Most physical sediment generation occurs during high energy events, with physical fragmentation of branched corals into coral sticks, being an obvious example, and one which yields large pulses of sediment (Scoffin 1993). The significance of this sediment source will again be strongly dependent upon the ecological make-up and species composition of the adjacent reefs. Bioerosion of reef substrate is facilitated by a wide range of reef-associated faunas, including various species of fish and echinoids, and endolithic forms of sponges, bivalves and worms. Framework degradation and sediment production by fish and echinoid species results as a by-product of the search for food. Parrotfish use their heavily calcified mouthparts to remove coral substrate, which is then excreted as sediment (Gygi 1975; Fig. 4), the size fraction increasing with fish size. Echinoids similarly produce sediment-rich faecal pellets (Scoffin et al. 1977; Fig. 4) with the grade of particles varying with genera, from coarse sands produced by Diadema sp. (Eakin 1996) to fine-medium sands by Echinometra sp. (Chazottes et al. 2004). Some species of endolithic bioeroders, and notably endolithic sponges of the genus Cliona, are also major sediment producers. These sponges excavate small fragments of coral skeleton which are subsequently expelled as sediment, mostly in the silt-size fraction (Fütterer 1974) (Fig. 4).

The relative abundance of these sediment producers varies markedly between reef zones and thus spatial variations in sediment yield, linked to reef ecological zonation patterns, are an inherent feature of most reef island systems. For example, at Warraber Island (Torres Strait) gastropods, sourced from sites proximal to the island, represent a key long-term source of 
island sediment, whilst other constituents (corals, foraminifera) are sourced from more distal sites on the reef flat (Woodroffe et al. 2006). In contrast, around Green Island (on the Great Barrier Reef) benthic foraminifera represent the major island sediment constituents, even though their contributions to total reef wide carbonate production is lower than that for corals and coralline algae (Yamano et al. 2000). Foraminifera are sourced primarily from the islands proximal shallow sand and reef flat habitats and seemingly preferentially transported to the islands. These differences in sediment sources are reflected in the different compositions of reef islands globally (see Fig. 5) and, despite inevitable local variations, some general observations regarding site locations and sediment compositions are evident: that benthic foraminifera are commonly the dominant sand-grade island sediment constituents in the Pacific, whilst Halimeda is dominant in the Caribbean. These regional differences are most likely a function of differential sea-level histories across the two regions and thus contemporary reef geomorphology: the highstand and regression across the Indo-Pacific (see Fig. 2) producing wide, tidally emergent reef flats, with these habitats favouring foraminifera production, whilst the shallow reef crests and lagoons that characterise the Caribbean favour Halimeda production.

\subsection{Post-production sediment alteration}

The structure of the biological sediment factory, as a function of reef habitat and ecology, thus acts as a primary control on the types and rates of sediment produced. Once released into the environment, most skeletal sediments are subject to a wide range of physical (e.g., abrasion), biological (e.g., microboring) and chemical (e.g., dissolution) processes (Perry 2000), that act to alter primary skeletal grain structure (and thus often to produce finergrained sediment constituents from previously larger bioclasts). Only grains that are rapidly entrained within the biological production zones and then moved quickly to accumulation 
zones are likely to survive in near-pristine condition. These post-mortem alteration (termed taphonomic) processes vary with environment and grain type, but can significantly modify the primary sedimentary properties of different constituents and, specifically, grain size, shape and effective density. In many cases, these pathways of degradation are predictable since they are largely determined by skeletal structure (the Sorby Principle; Sorby 1879). The calcified segments produced by Halimeda will, for example, typically degrade first into smaller segments and then disintegrate into fine-grained carbonate needles (Fig. 4). Thus both grain size and morphology change during breakdown. Conversely, the tests of foraminifera will, for many species, retain their primary skeletal morphology but be progressively reduced in size as they degrade (Kotler et al. 1992; Fig. 4).

\subsection{Controls on sediment transport from the biological sediment factory}

Variations in grain breakdown pathways clearly modify the general character of the sediment produced, but also, and perhaps more critically, dictate changes in grain size and morphology. These parameters, when considered alongside known differences in skeletal structure (effective density) and mineral density, govern the hydrodynamic behaviour of individual bioclasts and thus their transport potential - effectively controlling for a given wave/current energy regime which types of sediment are moved from particular habitats to adjacent island depositional centres (see Yamano et al. 2000). Such behaviour varies between skeletal constituents, and within constituent types, as they undergo post-mortem grain degradation (see Braithwaite 1973, Kench and McLean, 1996; Fig. 6), the nature of hydrodynamic behaviour change typically occurring as grain size and shape change (Fig. 6). For example, as plate-shaped grains (e.g. Marginopora sp.) initially fracture their settling rate increases. In contrast, spherical particles display a gradual reduction in settling velocity as size reduces (Fig. 6). There are also changes in the relative differences in settling velocities 
between grain types (Fig. 6) - differences being much greater for larger bioclasts when morphological and density differences are most pronounced. Consequently, under different hydrodynamic regimes, the type and grade of sediment that can be entrained and transported will vary markedly (Fig. 6B). This acts to further filter sediment supply, but in most systems sediments smaller than fine sand size have not been reported to make significant contributions to island construction (Folk \& Robles 1964; McLean \& Stoddart 1978; Yamano et al. 2000; Fuentes et al. 2010) - thus an effective grain-size threshold for land building can probably be considered for most reef islands (Fig. 4).

\subsection{Hierarchical controls on sediment production and transport}

The interactions between reef ecology (and changes therein), in associated sediment production, and in sediment hydrodynamic behaviour, allow an appreciation of the hierarchical nature of the controls that exist within the linked reef-island sediment system. The ecological state of the reef ecosystem (the biological sediment factory) acts as the primary control on the abundance of benthic sediment producers and this will clearly change temporally (Fig. 7A, B), but also spatially across individual environments (linked to the ecological zonation of the community). Once generated, the fate of sediment is then determined by a number of sedimentological properties (Fig. 7C) that determine (under a given hydrodynamic regime) the ultimate fate of sediment in the system - either being transported from the production sites, or retained in the environment of formation and subject to further taphonomic alteration (Fig. 7D). Thus, under a given environmental regime, some sediment constituents are more prone to selective removal and transportation to reef island shorelines, whilst other constituents are lost. 
The net effect of these interactions between benthic reef ecology, sediment generation and physical transport regimes, is that different islands often differ markedly in terms of both sediment composition and textural properties. Skeletal constituents present in islands seldom accurately reflect the proportions of active sediment producing organisms on surrounding reefs (Kench et al. 2005) and, as discussed, the contemporary sediment accumulation zones for many islands are composed of a narrow range of skeletal organisms usually dominated by coral, gastropods, foraminifera or Halimeda (see Fig. 5). In essence, the sedimentary system acts to effectively filter skeletal constituents so that for a given reef setting some constituents are more likely to dominate island sediments than others. In the context of projected impacts of environmental and ecological change, both on sediment generation and the physical environments around reef islands, this data can be used to compliment known island morphological response modes (discussed in Section 2) in order to consider the likely resilience of different island types based on their sediment compositions and the ecological sensitivity of different sediment producing species and ecological processes (see Section 5).

\section{Ecological change and changing patterns of sediment production}

Given the close links between benthic ecology, sediment production and landform construction, it is inevitable that factors driving ecological change must impact the rates and types of sediment produced. In the context of reef island development, changes in the character of sediment supply (volume and constituent mix) that arise from changes in reef species abundance or the rates at which ecological processes operate, can be highly significant with respect to continued building or maintenance of shorelines. Such ecological transitions can be driven either by natural changes in relative sea level (as controlled by vertical reef accretion), by natural disturbances (e.g., cyclones), by direct human disturbances (e.g., over-fishing, increased nutrient inputs), or by changes in marine environmental 
conditions (e.g., changes in ocean temperature or chemistry), and these can occur at a range of temporal scales (see Perry et al. 2008; Fig. 7A). Depending on the type of ecological change, sediment supply may be either 'turned on' or 'turned off' and can, therefore, regulate episodes of reef island construction. Below we consider several different scenarios where reef ecological change has driven changes in sediment production.

\subsection{Ecological-sedimentological links under changing reef growth-sea level conditions}

Continual adjustments between reef growth and sea level modulate relative water depth and wave energy conditions across reef surfaces and thus, in turn, govern the environmental conditions for ecological communities. The composition and abundance of species within the key shallow water sediment producing zones will inevitably respond to these changes, the nature of change being dependent upon the rate of reef accretion relative to sea-level change. For example, under a scenario of initially higher and then slightly falling towards present sealevels (analogous to the recent past across much of the Indo-Pacific; Woodroffe 2005; Dickinson 2009) the following basic stages of sea level-reef interactions can be considered: Stage 1 - reef shallowing as the reef accretes vertically to catch up with sea level; Stage 2 reef flat development after the reef has attained sea level; and Stage 3 - reef flat emergence under stable to slightly falling sea levels. Future increases in sea level, if reef flats cannot match the sea-level rise, will result in re-submergence (Stage 4).

The implications of these transitions in the context of the functioning of the biological sediment factory will vary in part depending on local reef community composition, but also spatially (as different reef zones change in different ways). In the Maldives, Kench et al. (2005) demonstrated the accumulation of Halimeda dominated sediments within the central areas of the reef platform, derived from the surrounding reefs, as the reefs accreted vertically 
to sea-level (analogous to Stage 1 above). As the reef reached sea level and reef flats evolved (Stages 2 and 3) production and supply of sediment from the biological factory shifted, such that coral and coralline algal particles became major sediment producers and constituents of the islands peripheral ridges. In southwest Japan, Yamano et al. (2001) showed that whilst corals and coralline algae were the major sediment producers as the reefs were accreting vertically to reach sea level (Stage 1), attainment of sea level followed by reef flat formation (Stages 2 and 3), resulted in a proliferation of benthic foraminifera, which then became major sediment producers as reef flat ecology changed. Similarly, at Green Island (Great Barrier Reef) Yamano et al. (2000) showed that reef flat development (Stage 2 above) transformed the ecological makeup of the Green Island reef flat to one where foraminifera were dominant, triggering island building.

Yamano (2000) also speculated on the future trajectories of contemporary sea-level constrained reefs in SW Japan by considering past ecological-sedimentary linkages as a guide to future change. Of critical importance is the ability of the reef crest communities to sustain or increase productivity to maintain their elevations relative to sea level. Any submergence of the reef flat (Stage 4 above) will force a suite of changes in the integrated sediment system that include: increased wave energy across reef surfaces; increased activation of the sediment transport system; and changes in habitat structure potentially causing loss of island building foraminifera species. The implications of these changes for island resilience are considered in more detail below.

\subsection{Ecological-sedimentological links under anthropogenically modified ecological states}

Linking anthropogenic disturbances and associated ecological changes to individual sedimentary responses is often difficult because of the inherent temporal lags that can exist 
between the 'impact' and the sedimentary response, and because environmental 'impacts' often operate in tandem (Przeslawski et al. 2008). However, the effects of two different types of human-induced ecological disturbances on sedimentary processes have been considered in sufficient detail to provide useful insights: the first linked to changes in water quality, the second to the loss of grazers and substrate eroders. Eutrophication is a widely discussed problem for many reef ecosystems, with changes in nutrient regimes linked to increased agricultural run-off and poor sewage management, and there has been extensive discussion of the potential consequences for the benthic ecology of reefs (Fabricius 2005). Whilst there is actually rather mixed evidence for the direct impacts upon benthic macroalgal productivity (discussed in Mumby et al. 2006), documented ecological changes and inferred or observed sedimentary responses include: an increase in the productivity of the calcareous green algae Halimeda (Smith et al. 1994) - a key sediment producer in many settings; increased benthic cover of crustose coralline algae (CCA) and some macroalgal species which can outcompete corals - this leading to an increased abundance of CCA in the sediment (Chazottes et al. 2008); reduced substrate grazing by fish and urchins due to higher algal biomass - leading to a reduction in the proportion of medium- to fine sand-sized sediments (500-125 $\mu \mathrm{m}$ fraction) (Chazottes et al. 2008); increased rates of internal bioerosion, especially by particulate feeders such as clionid sponges (Rose and Risk 1985, Edinger et al. 2000) - leading to a higher proportion of finer-grained ( $<125 \mu \mathrm{m}$ fraction) coral sediment (Lidz and Hallock, 2000) and; changes in benthic foraminifera population structures - resulting, for example, in a shift from larger symbiont bearing taxa such as Soritidae, to smaller heterotrophic taxa (Miliolidae and Rotaliidae) in the sediment (Cockey et al. 1996; Collen and Garton, 2004).

Sedimentary changes of a comparable magnitude can also be envisaged on reefs that have experienced major loss of key substrate grazing taxa, such as the parrotfish and urchins - 
changes resulting either from overfishing or mass mortality events (e.g., the 1983 regional mortality of the urchin Diadema in the Caribbean). Both groups of grazers produce, as a by-

product of grazing, significant quantities of coral and coralline algal-rich sediment. Selective removal of fish or urchins, or the entire loss of any other keystone species, may thus trigger changes in the types, rates and grain size of sediment produced (Bak 1990, Bruggeman et al. 1996), with potential knock-on effects for adjacent environments that depend upon sediment supply. The precise nature of the sedimentary impact will, however, depend both on the group of grazer concerned and on the size structure of the population affected, as both factors influence sediment type, grain size and rate of sediment production.

\section{Implications of ecological and environmental change for reef island resilience: a risk assessment of different island types}

Projecting future scenarios of island response to environmental change, especially under scenarios of rising global sea levels and changed ocean heat and chemistry, is a complex but critical issue. Central to the ability of reef islands to persist as sea levels rise will be the maintenance of an adequate supply of sediment, of suitable type and grade, for transport to and incorporation within island structures. In addition, the maintenance of the surrounding reef platform/rim, as a barrier to wave-attack will also be important (see Williams et al. 1999; Smithers et al. 2007). Neither, however, are likely to entirely mitigate against the likelihood of morphological and/or planform changes (Webb \& Kench 2010, Rankey 2011). An additional key issue however will be the composition and productivity of the contemporary biological sediment factory augmented, in some systems, by the (re)mobilisation of relict sediments stored on the reef flats and, in some systems, the release of a pulse of sediment from the breakdown of recently dead coral substrate. Clearly the links between ecology and sediment production are often complex and interacting, but preliminary morphological 
modelling shows that whilst sea-level rise alone drives some degree of morphological change on islands, the magnitude of change is significantly increased where reductions in sediment supply also occur, such as may occur as the ecology of the supply habitats change (Kench \& Cowell 2003).

Modelled outputs using the Modified Shoreface Translation Model (Kench \& Cowell 2001), for example, show that increased sea-levels alone could result in significant island morphological change (rollover and island migration - see Fig. 8), although morphological change clearly occurs much faster (for a given sea-level rise) on low elevation and narrow islands compared to wider, higher elevation islands (Fig. 8). These changes are essentially comparable to those observed on reef islands in the SW Pacific under rising sea levels (see Webb \& Kench 2010). Subsequent modelling using the same baseline datasets, but with forced scenarios of reduced sediment supply, operating in tandem with increased sea level resulted, however, in even more rapid and significant morphological change in the form of island migration across the platform (Kench \& Cowell, 2003) (Fig. 8), the magnitude of shoreline displacement increasing as the magnitude of reduced sediment supply increased.

Attempts to predict future island behaviour can also, to some degree, draw upon past records of sediment change, as derived from core studies through island fringing lagoons and from the reef islands themselves. These provide critical data on past transitions in sediment production regimes, often under conditions of rising sea-levels and/or vertical accretionary regimes. The studies by Woodroffe and Morrison (2001), Yamano et al. (2001) and Kench et al. (2005) document such responses over centennial to millennial timescales as islands have established and grown. The key question that arises, however, is what do such changes mean in the context of near-future reef island resilience and how susceptible are islands to 
ecologically-driven changes in sediment supply? To consider this it is necessary to understand what implications different ecological change scenarios have on reef ecology and thus sediment production in the surrounding areas of the biological sediment factory.

Using existing published data (see Section 4) it is possible to conceptually model the impacts of various ecological change scenarios on sediment production and, specifically, to consider how different ecological transitions may modify both the composition and grain-size of reef sediments generally. As an example we use here data from reef flat environments at Green Island, Australia (from Yamano et al. 2000) and evaluate the individual effects of increased sea level, marine eutrophication, and over-fishing on reef sediment assemblages (see Fig. 9). Under scenario 1 (path A to B) rising sea-levels result in a reduction in the production of foraminifera (change $b 2$ ), but increases in the abundance of Halimeda, coral and coralline algae, the latter two most likely in the coarse sand-gravel fraction (as a function of the physical destruction of coral substrate) (change $b 1$ ) and in the finer size fractions (change $b 3$ ) as substrate is opened up to bioerosion by grazers. Under scenario 2 (path A to C) coral and coralline algal cover reduces (change $c 1$ ), there is a marked increase in production of finegrained coral and coralline algal sediment due to increased sponge bioerosion (change $c 3$ ), and a marked reduction in the abundance of benthic foraminifera, especially larger symbiontbearing taxa such as Amphistegina, Marginopora and Calcarina (change c2) (Chazottes et al. 2008; Cockey et al. 1996; Collen and Garton 2004). Under scenario 3 (path A to D) loss of grazing fish and sea urchins will result in a reduction in the production of medium- to coarsegrained coral and coralline algal sands as larger grazers are lost (change $d 1$ ) and an increase in abundance of Halimeda and benthic foraminifera as they occupy more benthic substrate (change $d 2$ ). In all the scenarios above, ecological changes cause a change in the types and volumes of sediment of suitable grade for island-building. 
These observation provide an insight into the interactions between environmental (and associated ecological) change and sediment production. However, the more pressing question is what do such changes then mean for the actual structure and resilience of different types of reef islands i.e., those with different sediment compositional and textural characteristics. A series of preliminary predictive models for different island types can be developed using the data and concepts outlined previously, and specifically: i) published data on island sediment compositions (see Fig. 5); ii) data on sediment production responses to different environmental and ecological change scenarios (see Fig. 9); and iii) modelled responses of islands under changed sea level and sediment production regimes (see Fig. 8). In combination these can be used to assess the likely vulnerability of different (compositionally) island types as ecological changes drive transitions (both compositional and volumetric) in the abundance of island contributing sediments. The primary purpose of this is to demonstrate the critical role of ecologically-driven sediment supply (and changes therein) for subsequent landform change. Table 1 provides a synopsis of the links between physical environmental change, the associated biological and habitat responses, and subsequent projected changes in sediment production for five different ecological and environmental change scenarios. The possible spectrum of morphological responses of islands to these changes are summarised in Figure 10 and provide a basis to consider the veracity of assumptions underlying projected scenarios and consider the key sensitivities of islands to alterations in sediment supply.

Different types of ecological change drive different types of sediment production change, but the extent to which these exert an influence on island resilience will depend on island makeup (both in terms of predominant sediment type and grain size). Under all of the ecological change scenarios considered in Table 1 marked reductions in sand-grade coral sediment 
supply are projected, and thus one would project that islands composed predominantly of coral sands will show low levels of resilience to near-future ecological changes - these being manifested through increased rates of island washover, shoreward erosion and island migration (Figure 10c). Benthic foraminifera are likely to exhibit different responses to different ecological disturbances, both in terms of total production and species abundance. Thus under conditions of eutrophication (Table 1) a shift to greater production of smaller heterotrophic species is projected and these may be less suitable for island building resulting in island instability (Fig. 10c). However, total foraminifera production may increase under higher sea-surface temperatures partially offsetting any loss of habitats through increased sea levels and maintain island size (Fig. 10b). Thus foraminifera-dominated islands may experience different magnitudes of change depending on the suite of disturbances they face. Under most of the ecological change scenarios shown Halimeda are projected to increase their production, and thus islands composed primarily of this calcareous green algae may exhibit a higher degree of resilience either through progradation of ocean and lagoon shorelines (Fig. 10a) or maintenance of island size and position on its reef surface (Fig. 10b). Coral rubble dominated islands are likely to be relatively unaffected by changes in sandgrade sediment production, but are likely to undergo more significant morphological changes if coral rubble supply is increased due to higher turnover as a consequence of increased production and storminess (Fig. 10 a) or erode where reef recovery following storms is constrained (Fig. 10c).

As outlined above most scenarios of ecological change indicate negative shifts in the island sediment budget. The scenarios and possible morphological responses highlight some fundamental principles of relevance to future island change. First, islands dominated by a single sediment constituent are perhaps most susceptible to morphological change if 
ecological transitions impact that constituent. Second, where ecological change impacts island building sediments (either through changes in size or composition) ongoing maintenance of islands will necessitate a shift in key island building constituents. Historical analogues indicate that such shifts are possible as the relationship between sea level and reef ecology change. Island maintenance or expansion will require an increase in sediment supply either through a shift in sediment contributors or increased productivity and turnover of existing constituents. While most studies do not consider such outcomes, non-linear relationships between production under increased temperature regimes, higher turnover and breakdown of skeletal material affected by changes in ocean water chemistry (acidification), and changed littoral gradients, make such outcomes possible.

The above examples have been selected to demonstrate the types of morphological changes (and thus resilience potential) that can be predicted for different island types as ecological and environmental transitions modify sediment production regimes and rates. They estimate change for a range of relatively simplistic and individual change scenarios. In reality the near-future (ecological timescale) impacts on reef ecosystems (and thus reef islands) will be interacting and potentially cumulative. To consider these issues and better resolve the scenarios, higher resolution predictive approaches are required that integrate the more detailed modelling approaches recently developed to explore controls on reef ecosystem dynamics (Mumby 2006; Renken \& Mumby 2009). Such modelling attempts to simulate the linkages and feedbacks between reef ecological processes and reef benthos. From the perspective of integrating ecological-sediment production changes to island response modes, detailed parameterisation will be required of four sets of factors: 1) the rates, types and grades of sediment produced by different benthic taxa e.g., by different sized fish, urchins etc, and different ecological processes; 2) the hydrodynamic properties of these different sedimentary 
components; 3) the nature of change imposed by different environmental change factors on sediment production; and 4) the type and grade of sediments that contribute to islands. A significant amount of the required data to facilitate first order estimates of change currently exists in the literature, but for the most reliable modelling new data will be needed on various aspects of sediment production - including, especially, more reliable data on the rates of sediment production by different reef taxa and sediment producing processes (e.g., bioerosion by fish, urchins and sponges) and how these respond to ecological change, and field testing of the physical - sedimentological linkages that exist between the biological sediment factory and adjacent island shorelines.

The development of such models should, importantly, also allow the incorporation of future environmental and climatic change impacts on sediment production, these changes arising either as a function of benthic ecological change, or changes in the abundance of sediment producing taxa. In the context of the former, future increases in ocean heat content are likely to change reef ecosystems through more frequent and intense coral bleaching and mortality, as well as potentially impacting upon symbiont-bearing foraminifera and the growth rates of other key sediment producing taxa such as Halimeda and coralline algae (Baker et al. 2008; Przeslawski et al. 2011). Similarly, changes in ocean chemistry (ocean acidification) are projected to impact upon the calcification rates of numerous reef sediment producers (corals, foraminifera, Halimeda, molluscs, crustose coralline algae) and to change rates of calcification and skeletal density (Kuroyanagi et al. 2009; Ries et al. 2009). Climate shifts may also drive changes in the abundance of key sediment producing taxa, such as corallivore fish (e.g., Graham et al. 2011). This suite of climate change related disturbances will thus likely alter the nature of both reef communities and reef substrates (Hoegh-Guldberg et al. 2007) but also, as a consequence, both the amount and type of sediment produced. The 
degree of linearity that exists between these ecosystem changes and the sedimentary products are complex to predict, but modelling ecological-sedimentological interactions under these future change scenarios has the potential to provide important insights into future change dynamics on reef islands. Since these islands are home to a significant number of people and are unique oceanic ecosystems, both the societal and ecological relevance of such sedimentological studies are profound.

\section{Acknowledgements}

Contribution number RF-005 of the International Association of Geomorphologist's Working group REEForm. 


\section{References}

Alvarez-Filip L, Côté IM, Gill JA, Watkinson AR, Dulvy NK (2011) Region-wide temporal and spatial variation in Caribbean reef architecture: is coral cover the whole story? Global Change Biology, doi. 10.1111/j.1365-2486.2010.02385.x

Bak RPM (1990) Patterns of echinoid bioerosion in two Pacific coral reef lagoons. Marine Ecology Progress Series, 66, 267-272.

Baker AC, Glynn PW, Riegl B (2008) Climate change and coral reef bleaching: An ecological assessment of long-term impacts, recovery trends and future outlook. Estuarine, Coastal and Shelf Science, 80, 435-471.

Bellwood DR, Hughes TP, Folke C, Nyström M (2004) Confronting the coral reef crisis. Nature, 429, 827-833.

Braithwaite CJR (1973) Settling behaviour related to sieve analysis of skeletal sands. Sedimentology, 20, 251-262.

Bruggemann JH, Van Kessel AM, Van Rooij JM, Breeman AM (1996) Bioerosion and sediment ingestion by the Caribbean parrotfish Scarus vetula and Sparisoma viride: implications of fish size, feeding mode and habitat use. Marine Ecology Progress Series, 134, $59-71$.

Chazottes V, Chevillotte V, Dufresne A (2004) Characteristics of the particulate production by the sea urchin Echinometra mathaei on Indo-Pacigfic reefs: influence of coral communities and implications on the sedimentary dynamics. Geobios, 37, 13-22.

Chazottes V, Reijmer JJG, Cordier E (2008) Sediment characteristics in reef areas influenced by eutrophication-related alterations of benthic communities and bioerosion processes. Marine Geology, 250, 114-127. 
Church JA, White NJ, Hunter JR (2006) Sea-level rise at tropical Pacific and Indian Ocean islands. Global and Planetary Change 53, 155-168.

Cockey E, Hallock P, Lidz BH (1996) Decadal-scale changes in benthic foraminiferal assemblages off Key Largo, Florida. Coral Reefs, 15, 237-248.

Collen JD, Garton DW (2004) Larger foraminifera and sedimentation around Fongafale Island, Funafuti Atoll, Tuvalu. Coral Reefs, 23, 445-454.

Dawson JL, Smithers SG (2010) Shoreline and beach volume change between 1967 and 2007 at Raine Island, Great Barrier Reef, Australia. Global and Planetary Change, 72, 141-154.

Dickinson WR (2009) Pacific atoll living: how long already and until when? GSA Today, 19, 4-10.

Eakin CM (1996) Where have all the carbonates gone? A model comparison of calcium carbonate budgets before and after the 1982-1983 El Nino at Uva Island in the eastern Pacific. Coral Reefs, 15,109-119.

Edinger EN, Limmon GV, Jompa J, Widjatmoko W, Heikoop JM, Risk MJ (2000) Normal coral reef growth rates on dying reefs: Are coral growth rates good indicators of reef health? Marine Pollution Bulletin, 40, 404-425.

Emery KO, Tracey JI Jr, Ladd HS (1954) Geology of Bikini and nearby atolls. US Geological Survey Professional Paper, 260-A, 1-265.

Fabricius KE (2005) Effects of terrestrial runoff on the ecology of corals and coral reefs: review and synthesis. Marine Pollution Bulletin, 50, 125-146.

Folk RL, Robles R (1964) Carbonate sands of Isla Perez, Alacran Reef complex, Yucatán. Journal of Geology, 72, 255-292. 
Fuentes MMPB, Dawson J, Smithers S, Limpus CJ, Hamann M (2010). Sedimentological characteristics of key sea turtle rookeries: potential implications under projected climate change. Journal of Marine and Freshwater Research, 61, 464-473.

Fuentes MMPB, Limpus CJ, Hamann M (2011) Vulnerability of sea turtle nesting grounds to climate change. Global Change Biology, 17, 140-153.

Fütterer DK (1974) Significance of boring sponge Cliona for the origin of fine-grained material of carbonate sediments. Journal of Sedimentary Petrology, 44, 79-80.

Graham NAJ, Chabanet P, Evans RD et al. (2011) Extinction vulnerability of coral reef fishes. Ecology Letters doi: 10.1111/j.1461-0248.2011.01592.x

Gygi RA (1975) Sparisoma viride (the Stoplight Parrotfish), a major sediment producer on coral reefs of Bermuda. Ecologia et Geologica Helvetica, 68, 327-359.

Halfar J, Mutti M (2005) Global dominance of coralline red-algal facies: A response to Miocene oceanographic events. Geology, 33, 481-484.

Hallock P (2000) Larger foraminifers: Harbingers of global change? Micropaleontology, 46, 95-104.

Hoegh-Guldberg O, Mumby PJ, Hooten AJ et al. (2007) Coral reefs under rapid climate change and ocean acidification. Science, 318, 1737-1742.

Jackson JBC, Kirby MX, Berger, WH et al. (2001) Historical overfishing and the Recent collapse of coastal ecosystems. Science, 293, 629-638.

Kench PS (1997) Contemporary sedimentation in the Cocos (Keeling) Islands, Indian Ocean: interpretation using settling velocity analysis. Sedimentary Geology, 114, 109-130. 
Kench PS, Cowell PJ (2001) The morphological response of atoll islands to sea-level rise: Part 2: Application of the Modified Shoreface Translation Model (STM). Journal of Coastal Research Special Issue 34, 645-656.

Kench PS, McLean RF (1996) Hydraulic characteristics of bioclastic deposits: new possibilities for environmental interpretation using settling velocity fractions. Sedimentology, 43, 561-570.

Kench PS, Cowell PJ (2003) Variations in sediment production and implications for atoll island stability under rising sea level. Proceedings of $9^{\text {th }}$ International Coral Reef Symposium, Bali, October 23-27, 2000, 6p.

Kench PS, Brander RW (2006) Response of reef island shorelines to seasonal climate oscillations: South Maalhosmadulu atoll, Maldives. Journal of Geophysical Research, 11, F01001.

Kench PS, McLean RF, Nichol SL (2005) New model of reef-island evolution: Maldives, Indian Ocean. Geology, 33, 145-148.

Kench PS, Smithers SG, McLean RF, Nichol SL (2009) Holocene reef growth in the Maldives: evidence of a mid-Holocene sea-level highstand in the central Indian Ocean. Geology, 37, 455-458.

Kench P, Perry CT, Spencer T (2009) Coral Reefs. In: 'Geomorphology and Global Environmental Change: Landscape Scale Implications' (eds Slaymaker O, Spencer T, Embleton-Hamelin C) pp. 180-123. Cambridge University Press, Cambridge.

Kench PS, McLean RF, Brander RW, Nichol SL, Smithers SG, Ford MR, Parnell KE, Aslam M (2006) Geological effects of tsunami on mid-ocean atoll islands: the Maldives before and after the Sumatran tsunami. Geology, 34, 177-180.

Khan TMA, Quadir DA, Murty TS, Kabir A, Aktar F, Sarker MA (2002) Relative sea 
level changes in Maldives and vulnerability of land due to abnormal coastal inundation. Marine Geodesy, 25, 133-143.

Kotler E, Martin RE, Liddell WD (1992) Experimental analysis of abrasion and dissolution resistance of modern reef-dwelling foraminifera: implications for the preservation of biogenic carbonate. Palaios, 7, 244-276.

Kuroyanagi A, Kawahata H, Suzuki A et al. (2009) Impacts of ocean acidification on large benthic foraminifers: results from laboratory experiments. Marine Micropaleontology, 73, 190-195.

Lewis JB (2002) Evidence from aerial photography of structural loss of coral reefs at Barbados, West Indies. Coral Reefs, 21, 49-56.

Lidz BH, Hallock P (2000) Sedimentary petrology of a declining reef ecosystem, Florida Reef Tract (U.S.A.). Journal of Coastal Research, 16, 675-697.

McKee ED, Chronic J, Leopold EB (1959) Sedimentary belts in lagoon of Kapingamarangi Atoll. AAPG Bulletin, 43, 501-562.

McKoy H, Kennedy DM, Kench PS (2010) Sand cay evolution on reef platforms, Mamanuca Islands, Fiji. Marine Geology 269, 61-73.

McLean RF, Stoddart DR (1978) Reef island sediments of the northern Great Barrier Reef. Philosophical Transactions of the Royal Society of London A, 291, 101-117.

McLean RF, Woodroffe CD (1994) Coral atolls. In: Carter RWG, Woodroffe CD eds., Coastal Evolution: Late Quaternary Shoreline Morphodynamics, Cambridge University Press, Cambridge, pp. 267-302.

Milliman JD (1967) Carbonate sedimentation on Hogsty Reef, a Bahamian Atoll. Journal of Sedimentary Petrology, 37, 658-676. 
Mörner NA, Tooley M, Possnert G (2004) New perspectives for the future of the Maldives. Global and Planetary Change, 40, 177-182.

Mumby PJ (2006) The impact of exploiting grazers (Scaridae) on the dynamics of Caribbean coral reefs. Ecological Applications, 16, 747-769.

Mumby PJ, Hedley JD, Zychaluk K, Harborne AR, Blackwell PG (2006) Revisiting the catastrophic die-off of the urchin Diadema antillarum on Caribbean coral reefs: fresh insights on resilience from a simulation model. Ecological Modelling, 196, 131-148.

Nelson JE, Ginsburg RN (1986) Calcium carbonate production by epibionts on Thalassia in Florida Bay. Journal of Sedimentary Petrology, 56, 622-628.

Neumann AC, Land LS (1975) Lime mud deposition and calcareous algae in the Bight of Abaco, Bahamas: a budget. Journal of Sedimentary Petrology, 45, 763-786.

Osawa Y, Fujita K, Umezawa Y et al. (2010) Human impacts on large benthic foraminifers near a densely populated area of Majuro Atoll, Marshall Islands. Marine Pollution Bulletin, 60, 1279-1287.

Pandolfi JM, Bradbury RH, Sala E et al. (2003) Global trajectories of the long-term decline of coral reef ecosystems. Science, 301, 955-958.

Parry ML, Canziani OF, Palutikof JP, van der Linden PJ, Hanson CE (2007) Contribution of Working Group II to the Fourth Assessment Report of the Intergovernmental Panel on Climate Change, 2007. Cambridge University Press, Cambridge. UK.

Perry CT (1996) The rapid response of reef sediments to changes in community structure: implications for time-averaging and sediment accumulation. Journal of Sedimentary Research, 66, 459-467.

Perry CT, Spencer T, Kench P (2008) Carbonate budgets and reef production states: a geomorphic perspective on the ecological phase-shift concept. Coral Reefs, 27, 853-866. 
Perry CT (2000) Factors controlling sediment preservation on a north Jamaican fringing reef: a process based approach to microfacies analysis. Journal of Sedimentary Research, 70, 633648.

Przeslawski R, Ahyong S, Byrne M, Wörheides, Hutchings P (2008) Beyond corals and fish: the effects of climate change on noncoral benthic invertebrates of tropical reefs. Global Change Biology, 14, 2773-2795.

Rankey EC (2011) Nature and stability of atoll island shorelines: Gilbert Island chain, Kiribati, equatorial Pacific. Sedimentology doi: 10.1111/j.1365-3091.2011.01241.x

Renken H, Mumby PJ (2009) Modelling the dynamics of coral reef macroalgae using a Bayesian belief network approach. Ecological Modelling, 220, 1305-1314.

Ries JB, Cohen AL, McCorkle DC (2009) Marine calcifiers exhibit mixed responses to $\mathrm{CO}_{2}$ induced ocean acidification. Geology, 37, 1131-1134.

Risk MJ, Sammarco PW (1982) Bioerosion of corals and the influence of damselfish territoriality: a preliminary study. Oecologia, 52, 376-380.

Rose CS, Risk MJ (1985) Increase in Cliona delitrix infestation of Montastrea cavernosa heads on an organically polluted portion of the Grand Cayman fringing reef. Marine Ecology Publication della Staz, Zool di Napolii, 6, 345-363.

Roy P, Connell J (1991) Climate change and the future of atoll states. Journal of Coastal Research, 7, 1057-1075.

Scoffin TP (1993) The geological effects of hurricanes on coral reefs and the interpretation of storm deposits. Coral Reefs, 12, 203-221. 
Scoffin TP, Stearn CW, Boucher D, Frydl P, Hawkins CM, Hunter IG, McGeachy JK (1980) Calcium carbonate budget of a fringing reef on the west Coast of Barbados Part II - erosion, sediments and internal structure. Bulletin of Marine Science, 30, 475-508.

Schofield JC (1977) Effect of Late Holocene sea-level fall on atoll development. New Zealand Journal of Geology and Geophysics, 20, 531-536.

Sorby HC (1879) The Structure and Origin of Limestones. Proceedings of the Geological Society, London, 35, 56-95.

Smith JE, Smith CM, Vroom PS, Beach KL, Millers S (2004) Nutrient and growth dynamics of Halimeda tuna on Conch Reef, Florida Keys: possible influence of internal tides on nutrient status and physiology. Limnology and Oceanography, 49, 1923-1936.

Smithers SG, Harvey N, Hopley D, Woodroffe CD (2007) Vulnerability of Geomorphological features in the Great Barrier Reef to Climate Change. In: Johnson JE, Marshall PA (eds) Climate change and the Great Barrier Reef: A Vulnerability Assessment. Great Barrier Reef Marine Park Authority and the Australian Greenhouse Office, Townsville, pp667 - 716

Stoddart DR (1962) Three Caribbean atolls: Turneff Islands, Lighthouse Reef, and Glover's Reef, British Honduras. Atoll Research Bulletin, 87, 1-140.

Stoddart DR, Steers JA (1977) The nature and origin of coral reef islands. In: O.A. Jones and R. Endean, eds., Biology and Geology of Coral Reefs, vol. IV, Academic Press, New York, pp. 59-105.

Todd R (1960) Some observations on the distribution of Calcarina and Baculogypsina in the Pacific. Science Reports, Tohoku University, Sendai, Japan, 2nd Series (Geology) Special Volume, 4, 100-107. 
Toscano MA, Macintyre IG (2003) Corrected western Atlantic sea-level curve for the last 11,000 years based on calibrated ${ }^{14} \mathrm{C}$ dates from Acropora palmata framework and intertidal mangrove peats. Coral Reefs, 22, 257-270.

Tudhope AW, Scoffin TP, Stoddart DR, Woodroffe CD (1985) Sediments of Suwarrow Atoll. Proceedings of the $5^{\text {th }}$ International Coral Reef Congress, 6, 611-616.

Webb AP, Kench PS (2010) The dynamic response of reef islands to sea-level rise: evidence from multi-decadal analysis of island change in the Central Pacific. Global and Planetary Change, 72, 234-246.

Weber JN, Woodhead PMJ (1972) Carbonate lagoon and beach sediments of Tarawa Atoll, Gilbert Islands. Atoll Research Bulletin, 157, 1-21.

Williams, E.H.J., P.J. Bartels and L. Bunkey-Williams (1999) Predicted disappearance of coral-reef ramparts: a direct result of major ecological disturbances. Global Change Biology, 5, 839-845.

Woodroffe CD (1992) Morphology and evolution of reef islands in the Maldives. Proceedings of $7^{\text {th }}$ International Coral Reef Symposium, Guam, 2, 1217-1226.

Woodroffe CD (2002) Reef-island sedimentation on Indo-Pacific atolls and platform reefs. Proceedings of $9^{\text {th }}$ International Coral Reef Symposium, Bali, 2, 1187-1192.

Woodroffe CD (2005) Late Quaternary sea-level highstands in the central and eastern Indian Ocean: a review. Global and Planetary Change, 49, 121-138.

Woodroffe CD (2008) Reef-island topography and the vulnerability of atolls to sea-level rise. Global and Planetary Change, 62, 77-96.

Woodroffe CD, Morrison RJ (2001) Reef-island accretion and soil development on Makin, Kiribati, central Pacific. Catena, 44, 245-261. 
Woodroffe CD, McLean RF, Smithers SG, Lawson EM (1999) Atoll reef-island formation and response to sea-level change: West Island, Cocos (Keeling) Islands. Marine Geology, 160, 85-104.

Woodroffe CD, Kennedy DM, Hopley D, Rasmussen CE, Smithers SG (2000) Holocene reef growth in Torres Strait. Marine Geology, 170, 331-346.

Woodroffe CD, Samosorn B, Hua Q, Hart DE (2007) Incremental accretion of a sandy reef island over the past 3000 years indicated by component-specific radiocarbon dating. Geophysical Research Letters, 34, L03602.

Yamano H (2002) Sensitivity of reef flats and reef islands to sea-level change. Proceedings of $9^{\text {th }}$ International Coral Reef Symposium, Bali, 2, 1193-1198.

Yamano H, Miyajima T, Koike I (2000) Importance of foraminifera for the formation and maintenance of a coral sand cay: Green Island, Australia. Coral Reefs, 19, 51-58.

Yamano H, Kayanne H, Yonekura N (2001) Anatomy of a modern coral reef flat: a recorder of storms and uplift in the late Holocene. Journal of Sedimentary Research, 71, 295-304.

Yamano H, Kayanne H, Chikamori M (2005) An overview of the nature and dynamics of reef islands. Global Environmental Research, 9, 9-20.

Yamano H, Kayanne H, Yamaguchi T, Kuwahara Y, Yokofi H, Shimazaki H, Chikamori M (2007) Atoll island vulnerability to flooding and inundation revealed by historical reconstruction: Fongafale Islet, Funafutoi Atoll, Tuvalu. Global and Planetary Change, 57, 407-416. 


\section{Figures captions}

Fig. 1 Low lying reef islands and ecological-morphological links. Ecologically productive reefs such as this coral reef at Banyan Tree, Vabbinfaru, Maldives (A) and emergent foraminiferal rich reef flats, such as this in Ailinglaplap atoll, The Marshall Islands (B), control the type and grade of sediments generated on coral reefs. Both background hydrodynamic processes (waves and currents, C) and higher magnitude events (storms) interact with the sedimentary properties of clasts and preferentially transport sediment of island building size across reefs to form reef islands such as Fuagea, Funafuti atoll, Tuvalu (D). Such reefs islands are regarded as inherently vulnerable to sea-level rise through inundation and erosion.

Fig. 2 Age-depth plots for selected Indo-Pacific sites showing interpreted Holocene sea-level trends (thick grey line) and the inferred time periods over which reef islands have developed. A sea-level curve for the Caribbean is included, but whilst islands are clearly developed in various localities in this region their chronologies are very poorly understood. (A) IndoPacific: sea-level curve from Dickinson (2009); (B) Eastern Indian Ocean: sea level curve from Woodroffe et al. (1999); (C) Central Indian Ocean: sea level curve from Kench et al. (2009); (D) Caribbean: sea level curve from Toscano and Macintyre (2003).

Fig. 3 Schematic morphological response scenarios for reef-island formation over time. Numbers are indicative isochrons (timelines) of sediment accumulation in 1000 year intervals (adapted from Woodroffe 2002). For a more expanse range of morphological responses modes, that integrate temporal variations in accretion or erosion, see Woodroffe et al. (1999).

Fig. 4 Processes and pathways associated with the production and breakdown of a range of common bioclastic reef sediment constituents. Different producers and sources of sediment inherently produce sediment with different start point $\left(T_{0}\right)$ grain sizes. For some sediment sources (the very finest grained) limited further degradation occurs, but for many constituents subsequent reductions in grain size will occur. In some cases, this breakdown occurs in a discrete step-like fashion (shown with curved arrows; e.g., Halimeda $T_{0}-T_{1}-T_{2}$ ), this pathway being controlled by skeletal structure, but for other constituents the process is more gradational (shown with straight arrows) as abrasion progressively denudes the grain surfaces 
e.g., the physical abrasion of coral sticks. End-point grain sizes (the bold boxes to the right of each trajectory) are determined either by skeletal structure, breakdown pathway and time on that pathway, or by the sediment producing process itself. In most island systems a critical grain-size threshold point (grey boxed area to right of diagram) can be identified below which sediments are unlikely to be of a suitable grade for island construction.

Fig. 5. Dominant sedimentary constituents of reef islands reported from different sites globally. Adapted and updated from Yamano et al. (2005)

Fig. 6 (A) Variations in grain settling velocity against intermediate grain diameter for a range of common reef sediment constituents: 1 . Coral fragments; 2 . Halimeda segments; 3. Foraminifera (Marginopora - disk-shaped); 4. Echinoderm fragments; and 5. Bivalve shells (after Braithwaite 1973). Also shown are two hypothetical hydrodynamic regimes. Under regime 1 currents would be capable of entraining only fine-grained (less than $\sim 1 \mathrm{~mm}$ diameter) coral and echinoderm fragments, but also bivalves to $\sim 2.5 \mathrm{~mm}$ diameter and all size fractions of Halimeda and Marginopora grains. However, under higher hydrodynamic regimes (regime 2) currents should be able to entrain all Halimeda, Marginopora and echinoderm material, as well as coral to $\sim 4 \mathrm{~mm}$ diameter, and bivalves to $\sim 10 \mathrm{~mm}$ diameter. (B) Threshold velocity vs. mean settling velocity of composite bioclastic sediment fractions and individual bioclastic constituents. Measured velocities $0.025 \mathrm{~m}$ above sediment surface. After Kench and McLean (1996).

Fig. 7 Hierarchy of controls on sediment generation and transport in reef-reef island systems, and sedimentary responses to ecological transitions. Hypothetical ecological states and transitions over time (A) as reflected by differences in benthic community structure and the abundance of key sediment producers (parrotfish, sea urchins; Bellwood et al. 2004). Different ecological states will produce different sediment assemblages (B) reflected by variations in the abundance of individual sediment constituents ( $a, b, c$ etc). The response of individual constituents to different ecological changes is likely to vary. In this hypothetical example, constituent ' $a$ ' responds in a linear way, abundance changing very rapidly after each ecological transition; constituent ' $b$ ' however, has a non-linear response, such that a marked lag occurs between the ecological transition and constituent abundance change; constituent 'c' exhibits mixed responses with a non-linear response to ecological transition 1 , but a 
linear response to transition 2. Each constituent will subsequently vary in terms of entrainment/transport potential under a given hydrodynamic regime as controlled by a suite of sedimentological parameters (C). These will determine the immediate fate of constituents (D): being either retained on the reef (Pathway A) and either lost to the active sediment reservoir through incorporation in the reef structure (A1), or further degraded and made reavailable for later transport (A2); or transported (Pathway B) either to nodal locations of accumulation e.g., reef islands (B1), or flushed off-reef (B2).

Fig. 8 Simulations of island morphological responses to combined sea-level rise and altered sediment supply regimes based on the Modified Shoreface Translation Model. In (A) the effects of sea-level rise alone are modelled for both (a) low elevation, narrow reef islands, and (b) wide, higher elevation reef islands (adapted from Kench \& Cowell 2001). In (B) the effects of both sea-level rise and reduced sediment supply are modelled: (a) baseline state; (b) effects of a $0.9 \mathrm{~m}$ sea-level rise alone; (c) $0.9 \mathrm{~m}$ sea-level rise and reduced sediment supply; and (d) $0.9 \mathrm{~m}$ sea-level rise and much larger magnitude of reduced sediment supply (adapted from Kench \& Cowell 2003). Thick black line shows the final morphological state of the islands aftereach scenario run, and the dashed lines the effects of sequential $0.1 \mathrm{~m}$ increases during each rise. Study based on data from Buariki on Tawara Atoll, Kiribati.

Fig. 9 Conceptual modelled examples of the effects of ecological change on reef flat sediment production: Path A to B is driven by sea-level rise; Path A to $\mathrm{C}$ by eutrophication; and Path A to D by over-fishing (see text for explanation). The grain size threshold point below which sediment is unlikely to be of suitable size for island construction is shown with the grey vertical line and grey boxed zone.

Fig. 10 Projected styles of island morphological responses to sea level change and altered sediment supply regimes, many of which can occur as a response to ecological change (see Table 1). $T_{0}$ represents current island morphology $T_{1}-T_{3}$ represent future morphological trajectories of islands. A simplified island morphology has been selected to demonstrate the range of responses. 


\section{Table captions}

Table 1. Synthesis of projected physical environmental changes, linked biological and habitat changes, and subsequent anticipated sedimentary responses to a range of near-future ecological and environmental change scenarios . References: [1] Yamano 2002); [2] Cockey et al. (1996); [3] Collen and Garton (2004); [4] Smith et al. (1994); [5] Chazottes et al. (2008); [6] Rose and Risk (1985); [7] Edinger et al. (2000); [8] Lidz and Hallock (2000); [9] Bak (1990); [10] Bruggeman et al. (1996); [11] Hallock (2000); [12] Baker et al. (2008); [13] Halfar and Mutti (2005). 


\begin{tabular}{|c|c|c|c|c|c|}
\hline & $\begin{array}{l}\text { Scenario 1: } 0.5 \mathrm{~m} \text { sea- } \\
\text { level rise + steady state } \\
\text { sediment production } \\
\text { and supply }\end{array}$ & $\begin{array}{l}\text { Scenario 2: } 0.5 \mathrm{~m} \text { sea- } \\
\text { level rise + benthic } \\
\text { ecological change } \\
\text { driven by eutrophication }\end{array}$ & $\begin{array}{l}\text { Scenario 3: } 0.5 \mathrm{~m} \text { sea- } \\
\text { level rise + benthic } \\
\text { ecological change } \\
\text { driven by over-fishing }\end{array}$ & $\begin{array}{l}\text { Scenario 4: } 0.5 \mathrm{~m} \text { sea- } \\
\text { level rise + benthic } \\
\text { ecological change } \\
\text { driven by sea-surface } \\
\text { temp. change }\end{array}$ & $\begin{array}{l}\text { Scenario } 5: 0.5 \mathrm{~m} \text { sea- } \\
\text { level rise + benthic } \\
\text { ecological change } \\
\text { driven by sea-surface } \\
\text { temp. change + } \\
\text { increased storminess }\end{array}$ \\
\hline $\begin{array}{l}\text { Physical } \\
\text { Environmental } \\
\text { Change }\end{array}$ & $\begin{array}{l}\text { Gradual submergence of } \\
\text { reef flat. } \\
\text { Opening of wave energy } \\
\text { window*. }\end{array}$ & $\begin{array}{l}\text { Gradual submergence of } \\
\text { reef flat. } \\
\text { Opening of wave energy } \\
\text { window. } \\
\text { Change in water quality. }\end{array}$ & $\begin{array}{l}\text { Gradual submergence of } \\
\text { reef flat. } \\
\text { Opening of wave energy } \\
\text { window*. }\end{array}$ & $\begin{array}{l}\text { Gradual submergence of } \\
\text { reef flat. } \\
\text { Opening of wave energy } \\
\text { window*. }\end{array}$ & $\begin{array}{l}\text { Gradual submergence of } \\
\text { reef flat. } \\
\text { Opening of wave energy } \\
\text { window*. } \\
\text { Increase in high energy } \\
\text { events. }\end{array}$ \\
\hline $\begin{array}{l}\text { Biological/habitat } \\
\text { response }\end{array}$ & $\begin{array}{l}\text { Transition to shallow } \\
\text { submerged reef flats. } \\
\text { Progressive recolonisation } \\
\text { by corals and coralline } \\
\text { algae. } \\
\text { Opening up of new } \\
\text { substrate to fish and } \\
\text { urchin grazers. }\end{array}$ & $\begin{array}{l}\text { Transition to shallow } \\
\text { submerged reef flats. } \\
\text { Opening up of new } \\
\text { substrate to fish and } \\
\text { urchin grazers. } \\
\text { Shift in benthic habitat } \\
\text { productivity(calcareous } \\
\text { and non-calcareous } \\
\text { macroalgae, foraminifera). } \\
\text { Increased fiter feeder } \\
\text { productivity. }\end{array}$ & $\begin{array}{l}\text { Transition to shallow } \\
\text { submerged reef flats. } \\
\text { Reduced abundance of } \\
\text { grazing fish. } \\
\text { Possible compensatory } \\
\text { increase in grazing urchin } \\
\text { densities. }\end{array}$ & $\begin{array}{l}\text { Transition to shallow } \\
\text { submerged reef flats. } \\
\text { Increased coral mortality } \\
\text { Suppressed recolonisation } \\
\text { by corals and coralline } \\
\text { algae. } \\
\text { Increased abundance of } \\
\text { other symbiont-bearing } \\
\text { sediment producers } \\
\text { (some foraminifera). }\end{array}$ & $\begin{array}{l}\text { Transition to shallow } \\
\text { submerged reef flats. } \\
\text { Increased coral mortality } \\
\text { Suppressed recolonisation } \\
\text { by corals and coralline } \\
\text { algae. } \\
\text { Increased abundance of } \\
\text { other symbiont-bearing } \\
\text { sediment producers } \\
\text { (some foraminifera). }\end{array}$ \\
\hline $\begin{array}{l}\text { Projected } \\
\text { sedimentary } \\
\text { response }\end{array}$ & $\begin{array}{l}\text { Reduced overall } \\
\text { production of benthic } \\
\text { foraminifera [1]. } \\
\text { Increased production of } \\
\text { corals (after initial lag) [1]. } \\
\text { Increased production by } \\
\text { crustose coralline algae } \\
\text { and Halimeda [1]. }\end{array}$ & $\begin{array}{l}\text { Change in benthic } \\
\text { foraminifera production } \\
\text { (more small species) }[2,3] \text {. } \\
\text { Increased production by } \\
\text { crustose coralline algae } \\
\text { and Halimeda }[1,4,5] \text {. } \\
\text { Increased fine coral } \\
\text { sediment production from } \\
\text { infaunal bioeroders } \\
{[6,7,8] .}\end{array}$ & $\begin{array}{l}\text { Reduced overall } \\
\text { production of benthic } \\
\text { foraminifera [1]. } \\
\text { Reduced production of } \\
\text { grazing-derived coral and } \\
\text { coralline algal sediment } \\
{[9,10] .} \\
\text { Increased crustose } \\
\text { coralline algae and } \\
\text { Halimeda production [1]. }\end{array}$ & $\begin{array}{l}\text { Limited overall change in } \\
\text { production of benthic } \\
\text { foraminifera [11]. } \\
\text { Initial increase in rubble- } \\
\text { grade coral production } \\
\text { and subsequently coral } \\
\text { sediment [12]. } \\
\text { Increased production by } \\
\text { crustose coralline algae } \\
\text { and Halimeda }[1,13] \text {. }\end{array}$ & $\begin{array}{l}\text { Limited overall change in } \\
\text { production of benthic } \\
\text { foraminifera [11.] } \\
\text { Initial increase in rubble- } \\
\text { grade coral production } \\
\text { and subsequently coral } \\
\text { sediment [12]. } \\
\text { Increased production by } \\
\text { crustose coralline algae } \\
\text { and Halimeda [1,13]. } \\
\text { Increased sediment } \\
\text { transport. }\end{array}$ \\
\hline
\end{tabular}

${ }^{*}$ Assumes a temporal lag in reef rim catch up as reef flat communities adjust to increased water depths and wave energy 

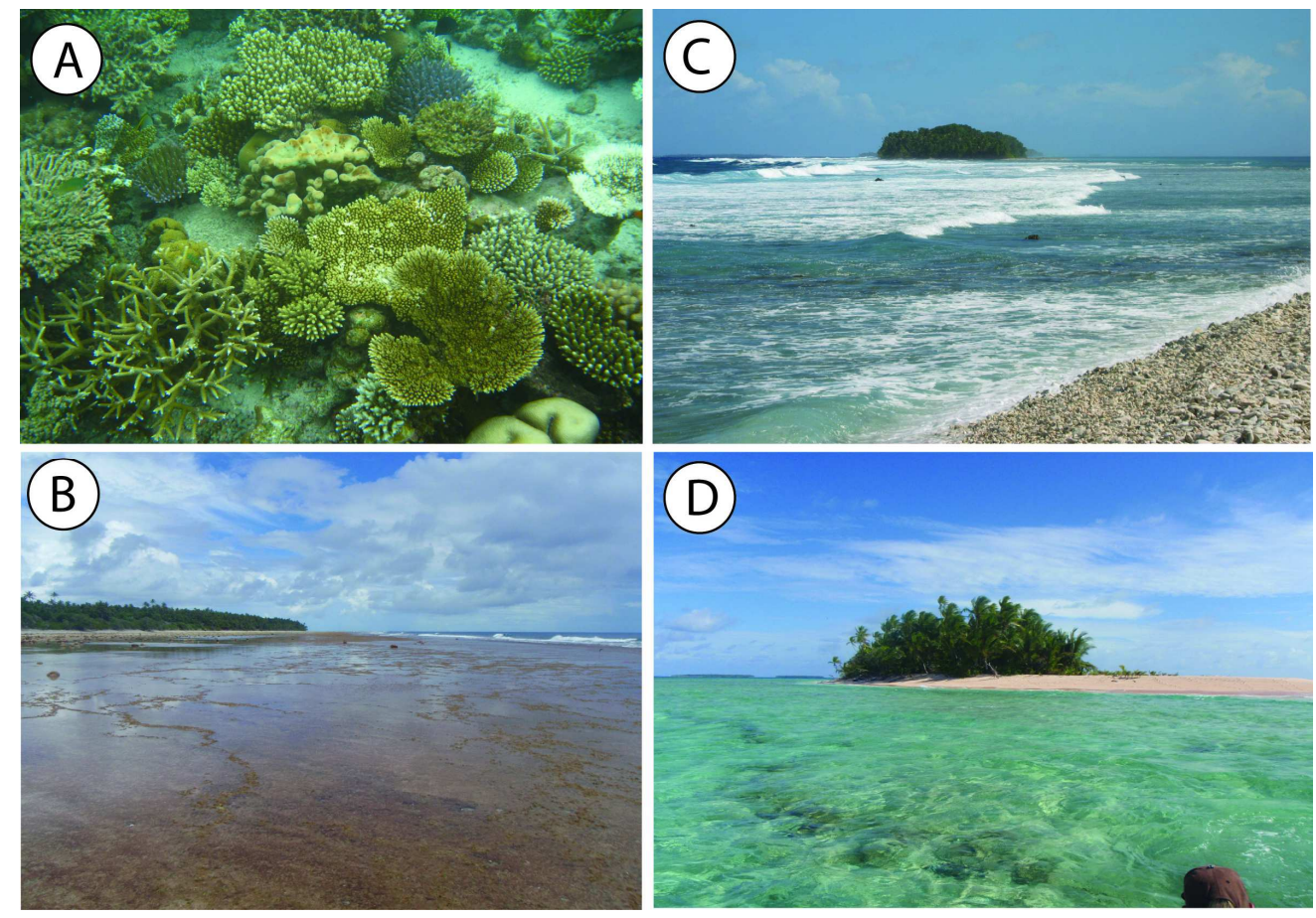

Fig. 1 Low lying reef islands and ecological-morphological links. Ecologically productive reefs such as this coral reef at Banyan Tree, Vabbinfaru, Maldives (A) and emergent foraminiferal rich reef flats, such as this in Ailinglaplap atoll, The Marshall Islands (B), control the type and grade of sediments generated on coral reefs. Both background hydrodynamic processes (waves and currents, C) and

higher magnitude events (storms) interact with the sedimentary properties of clasts and preferentially transport sediment of island building size across reefs to form reef islands such as Fuagea, Funafuti atoll, Tuvalu (D). Such reefs islands are regarded as inherently vulnerable to sealevel rise through inundation and erosion. 


\section{(A) Pacific Ocean}

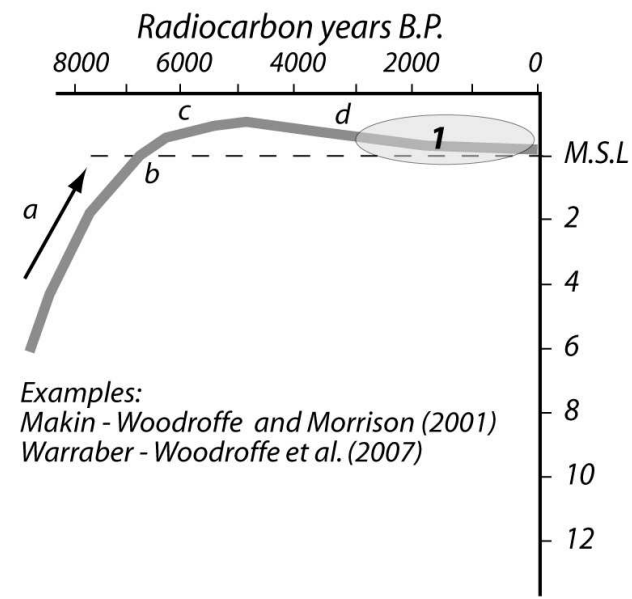

(C) Central Indian Ocean

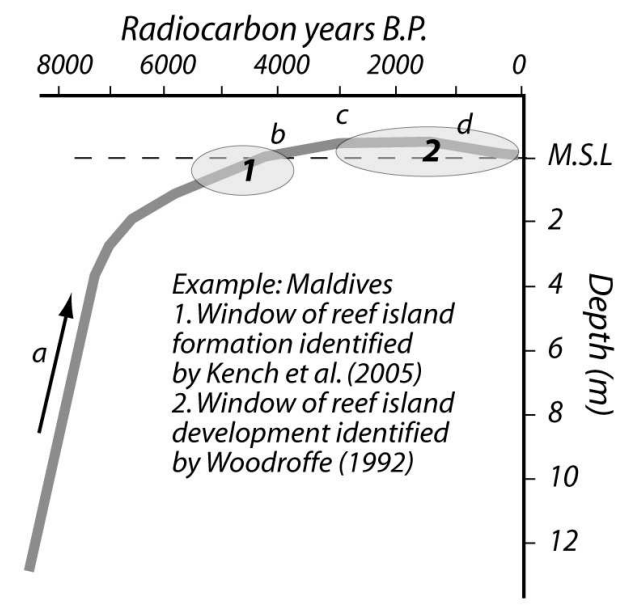

\section{(B) Eastern Indian Ocean)}

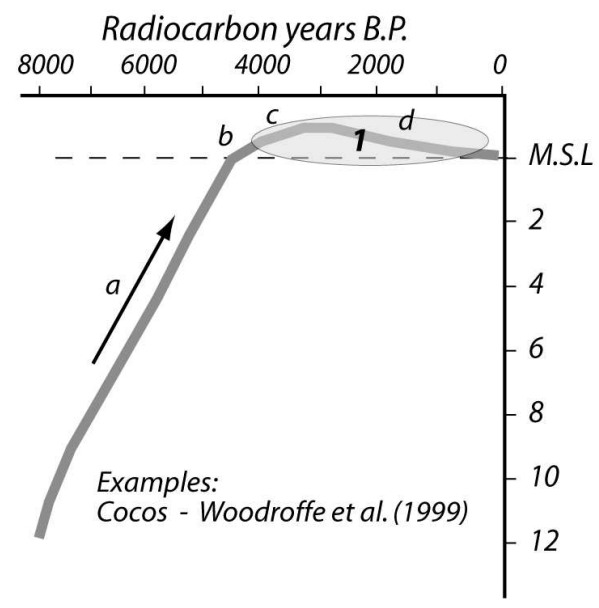

\section{(D) Caribbean}

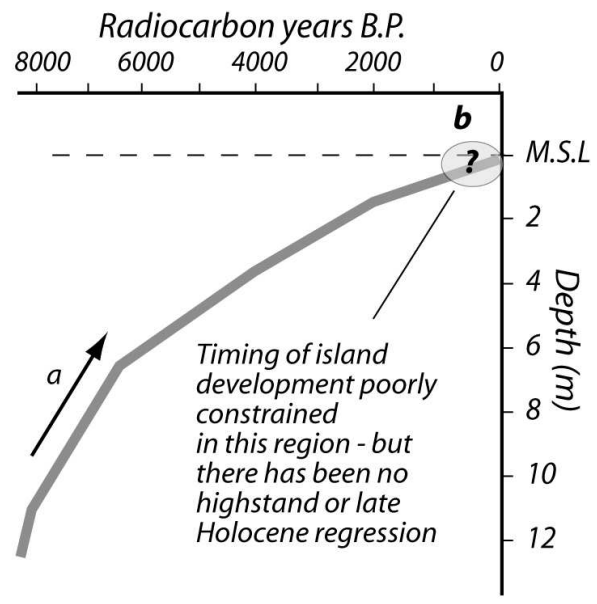

$a$ - Catch-up reef growth during transgression

$b$-Time modern sea-level first attained

c-Reef flat/platform development

$d$-Post-highstand regression

1. Identified period of reef island development

Fig. 2 Age-depth plots for selected Indo-Pacific sites showing interpreted Holocene sea-level trends (thick grey line) and the inferred time periods over which reef islands have developed. A sea-level curve for the Caribbean is included, but whilst islands are clearly developed in various localities in this region their chronologies are very poorly understood. (A) Indo-Pacific: sea-level curve from

Dickinson (2009); (B) Eastern Indian Ocean: sea level curve from Woodroffe et al. (1999); (C) Central Indian Ocean: sea level curve from Kench et al. (2009); (D) Caribbean: sea level curve from Toscano and Macintyre (2003). $127 \times 163 \mathrm{~mm}(300 \times 300$ DPI $)$ 

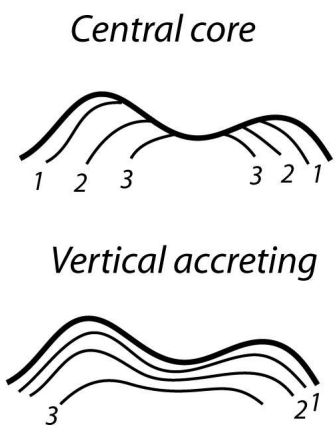

Single episode

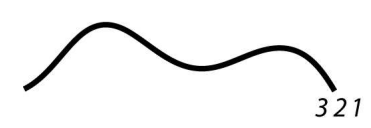

Oceanward accretion

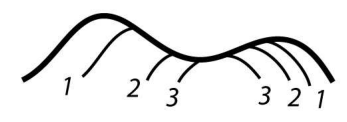

Rollover

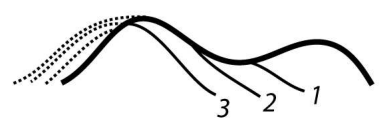

Erosional remnant

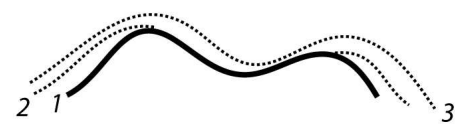

Lagoonward accretion

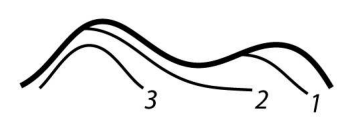

Overwash

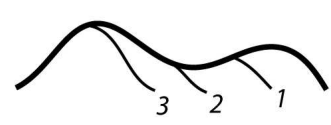

Longshore

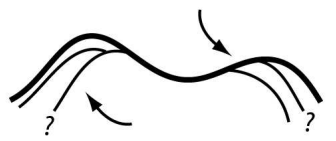

Fig. 3 Schematic morphological response scenarios for reef-island formation over time. Numbers are indicative isochrons (timelines) of sediment accumulation in 1000 year intervals (adapted from Woodroffe 2002). For a more expanse range of morphological responses modes, that integrate temporal variations in accretion or erosion, see Woodroffe et al. (1999).

$165 \times 82 \mathrm{~mm}(300 \times 300 \mathrm{DPI})$ 


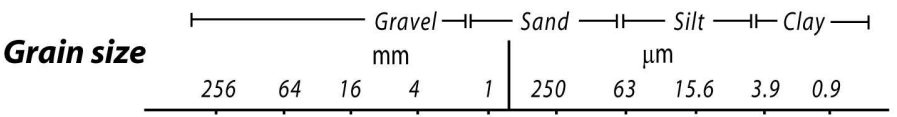

\section{Primary skeletal sediment production}

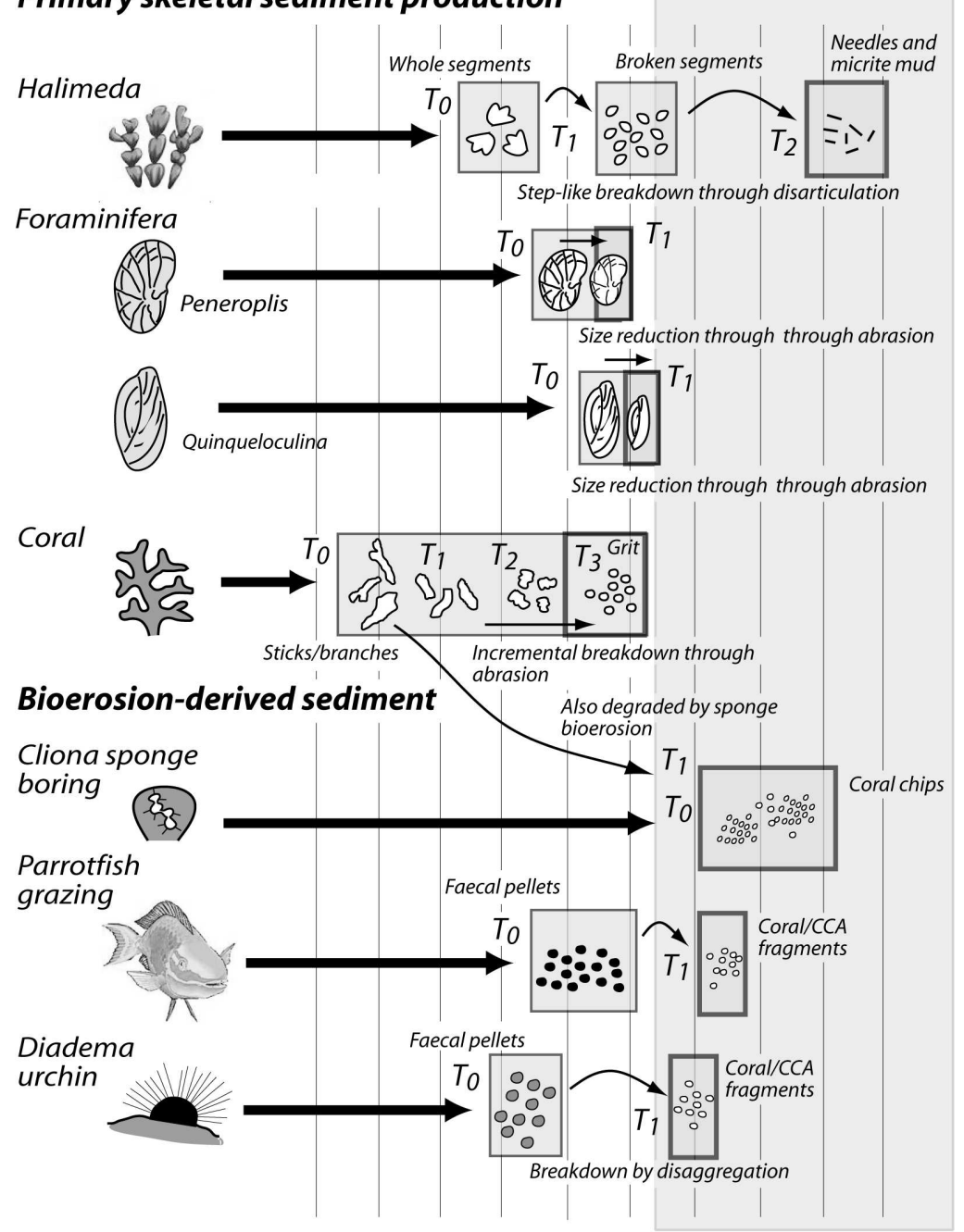

NB. Different bioclasts will undergo breakdown at different rates in different reef environments

Fig. 4 Processes and pathways associated with the production and breakdown of a range of common bioclastic reef sediment constituents. Different producers and sources of sediment inherently produce sediment with different start point (T0) grain sizes. For some sediment sources (the very finest grained) limited further degradation occurs, but for many constituents subsequent reductions in grain size will occur. In some cases, this breakdown occurs in a discrete step-like fashion (shown with curved arrows; e.g., Halimeda T0-T1-T2), this pathway being controlled by skeletal structure, but for other constituents the process is more gradational (shown with straight arrows) as abrasion progressively denudes the grain surfaces e.g., the physical abrasion of coral sticks. End-point grain sizes (the bold boxes to the right of each trajectory) are determined either by skeletal structure, breakdown pathway and time on that pathway, or by the sediment producing process itself. In most island systems a critical grain-size threshold point (grey boxed area to right of diagram) can be identified below which sediments are unlikely to be of a suitable grade for island construction. 


\begin{tabular}{|c|c|c|c|c|c|c|c|c|}
\hline \multirow[t]{2}{*}{ Site } & Island type & \multirow[t]{2}{*}{ Reef type } & \multicolumn{5}{|c|}{ Contemporary constituents } & \multirow[t]{2}{*}{ Reference } \\
\hline & & & C & CCA & $\mathrm{H}$ & $\mathrm{F}$ & $M$ & \\
\hline \multicolumn{9}{|l|}{ Indian Ocean } \\
\hline 1. Maldives & Cay & Atoll & & & & & & Woodroffe (1992) \\
\hline 2. Maldives (various) & Cay & Atoll & - & 0 & 0 & & & Kench et al. (2005) \\
\hline 3. Cocos (Keeling) & Motu & Atoll & 0 & 0 & & - & & Woodroffe et al. (1999) \\
\hline \multicolumn{9}{|l|}{ Pacific Ocean } \\
\hline 4. Kapingamara & Motu & Atoll & 0 & & & & 0 & McKee et al. (1959) \\
\hline 5. Eniwetok, Marshall Isl. & Motu & Atoll & & & & & & Emery et al.(1954), Todd (1960) \\
\hline 6. Bikini, Marshall Isl. & Motu & Atoll & 0 & 0 & & 0 & & Emery et al.(1954), Todd (1960) \\
\hline 7. Rongelap, Marshall Isl. & Motu & Atoll & & & & & 0 & Emery et al.(1954), Todd (1960) \\
\hline 8. Rongerik, Marshall Isl. & Motu & Atoll & & & & & & Emery et al.(1954), Todd (1960) \\
\hline 9. Makin, Kiribati & Motu & Table reef & & & & & & Woodroffe and Morrison (2001) \\
\hline 10. Tarawa, Kiribati & Motu & Atoll & & & & 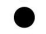 & & Weber and Woodhead (1972) \\
\hline 11. Tarawa, Kiribati & Motu & Atoll & & & & & & Schofield (1977) \\
\hline 12. Butaritari, Kiribati & Motu & Atoll & & & & & 0 & Schofield (1977) \\
\hline 13. Funafuti, Tuvalu & Motu & Atoll & 0 & 0 & 0 & 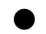 & & Collen and Garton (2004) \\
\hline 14. Suwarrow, Cook Isl. & Muto & Atoll & O & O & 0 & $\mathbf{0}$ & & Tudhope et al. (1985) \\
\hline 15. Mamanuca Isl. & Cay & Patch reef & - & & 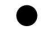 & & & McKoy et al. (2010) \\
\hline 16. Various, GBR & Cay & Platform reef & & & & 0 & & McLean and Stoddart (1978) \\
\hline 17. Green Island, GBR & Cay & Platform reef & 0 & $\mathrm{O}$ & & & 0 & Yamano et al. (2000) \\
\hline 18. Raine Island, GBR & Cay & Platform reef & & & & & 0 & Dawson and Smithers (2010) \\
\hline 19.Various, GBR & Cay & Platform reef & & & & & 0 & Fuentes et al.(2010) \\
\hline \multicolumn{9}{|l|}{ Caribbean } \\
\hline 20. Alacran Reef & Cay & Atoll & 0 & & - & & & Folk and Robles (1964) \\
\hline 21. Turneffe Isl. & Cay & Atoll & 0 & & 0 & & & Stoddart (1962) \\
\hline 22. Lighthouse Reef & Cay & Atoll & 0 & & & & & Stoddart (1962) \\
\hline 23. Glover's Reef & Cay & Atoll & 0 & & & & & Stoddart (1962) \\
\hline 24. Hogsty Reef & Cay & Atoll & 0 & 0 & & & 0 & Milliman (1967) \\
\hline Major con & it & Minor co & & & & & & \\
\hline
\end{tabular}

Fig. 5. Dominant sedimentary constituents of reef islands reported from different sites globally. Adapted and updated from Yamano et al. (2005) $195 \times 151 \mathrm{~mm}(300 \times 300 \mathrm{DPI})$ 

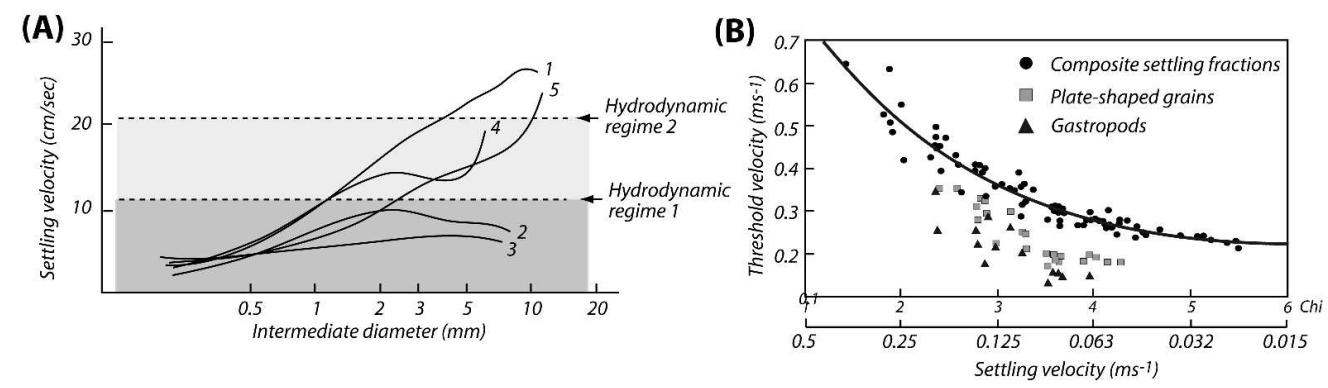

Fig. 6 (A) Variations in grain settling velocity against intermediate grain diameter for a range of common reef sediment constituents: 1 . Coral fragments; 2 . Halimeda segments; 3 . Foraminifera (Marginopora - disk-shaped); 4. Echinoderm fragments; and 5. Bivalve shells (after Braithwaite 1973). Also shown are two hypothetical hydrodynamic regimes. Under regime 1 currents would be capable of entraining only fine-grained (less than $\sim 1 \mathrm{~mm}$ diameter) coral and echinoderm fragments, but also bivalves to $\sim 2.5 \mathrm{~mm}$ diameter and all size fractions of Halimeda and Marginopora grains. However, under higher hydrodynamic regimes (regime 2) currents should be able to entrain all Halimeda, Marginopora and echinoderm material, as well as coral to $\sim 4 \mathrm{~mm}$ diameter, and bivalves to $\sim 10 \mathrm{~mm}$ diameter. (B) Threshold velocity vs. mean settling velocity of composite bioclastic sediment fractions and individual bioclastic constituents. Measured velocities $0.025 \mathrm{~m}$ above sediment surface. After Kench and McLean (1996).

$266 \times 76 \mathrm{~mm}(300 \times 300 \mathrm{DPI})$ 


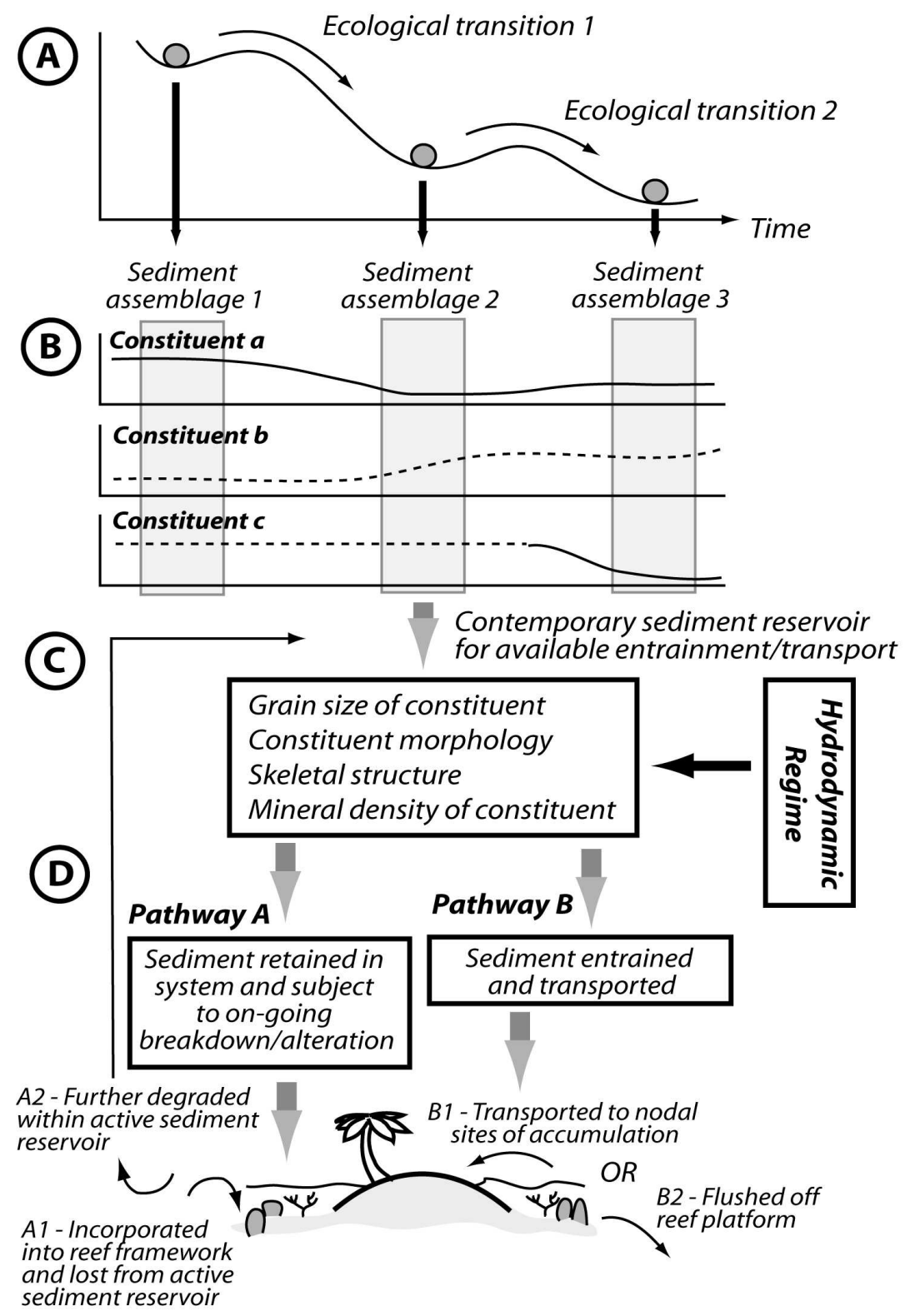

Fig. 7 Hierarchy of controls on sediment generation and transport in reef-reef island systems, and sedimentary responses to ecological transitions. Hypothetical ecological states and transitions over time $(A)$ as reflected by differences in benthic community structure and the abundance of key sediment producers (parrotfish, sea urchins; Bellwood et al. 2004). Different ecological states will produce different sediment assemblages (B) reflected by variations in the abundance of individual sediment constituents ( $a, b, c$ etc). The response of individual constituents to different ecological changes is likely to vary. In this hypothetical example, constituent 'a' responds in a linear way, abundance changing very rapidly after each ecological transition; constituent ' $b$ ' however, has a non-linear response, such that a marked lag occurs between the ecological transition and constituent abundance change; constituent ' $c$ ' exhibits mixed responses with a non-linear response to ecological transition 1, but a linear response to transition 2 . Each constituent will subsequently vary in terms of entrainment/transport potential under a given hydrodynamic regime as controlled by a suite of sedimentological parameters $(C)$. These will determine the immediate fate of 
constituents (D): being either retained on the reef (Pathway A) and either lost to the active sediment reservoir through incorporation in the reef structure (A1), or further degraded and made re-available for later transport (A2); or transported (Pathway $B$ ) either to nodal locations of accumulation e.g., reef islands (B1), or flushed off-reef (B2). $124 \times 183 \mathrm{~mm}(300 \times 300 \mathrm{DPI})$ 
(A)

(a) Low elevation, narrow island

State 1:Present connditions

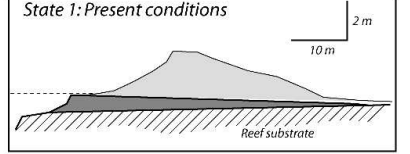

State 2:0.5 m SLR

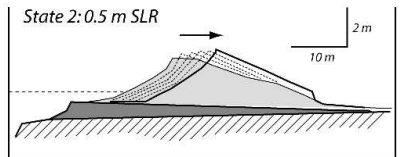

Sea-level rise only

(b) High elevation, wide island
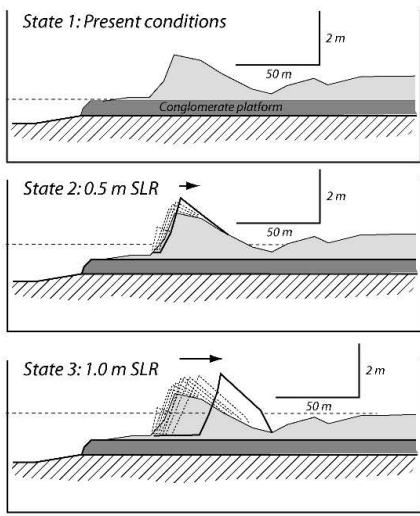

(B) Sea-level rise and reduced sediment supply

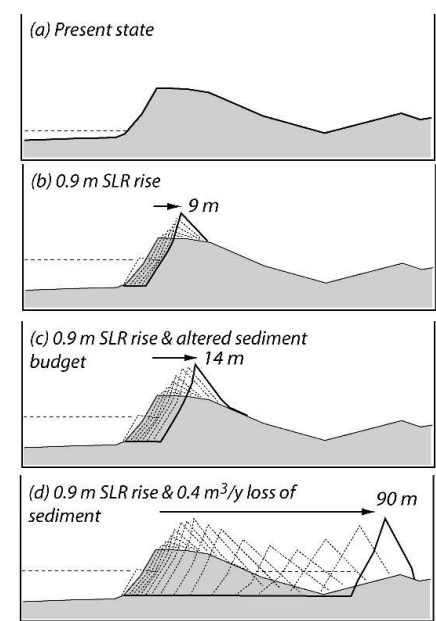

Fig. 8 Simulations of island morphological responses to combined sea-level rise and altered sediment supply regimes based on the Modified Shoreface Translation Model. In (A) the effects of sea-level rise alone are modelled for both (a) low elevation, narrow reef islands, and (b) wide, higher elevation reef islands (adapted from Kench \& Cowell 2001). In (B) the effects of both sealevel rise and reduced sediment supply are modelled: (a) baseline state; (b) effects of a $0.9 \mathrm{~m}$ sealevel rise alone; (c) $0.9 \mathrm{~m}$ sea-level rise and reduced sediment supply; and (d) $0.9 \mathrm{~m}$ sea-level rise and much larger magnitude of reduced sediment supply (adapted from Kench \& Cowell 2003). Thick black line shows the final morphological state of the islands aftereach scenario run, and the dashed lines the effects of sequential $0.1 \mathrm{~m}$ increases during each rise. Study based on data from Buariki on Tawara Atoll, Kiribati. $281 \times 151 \mathrm{~mm}(300 \times 300 \mathrm{DPI})$ 


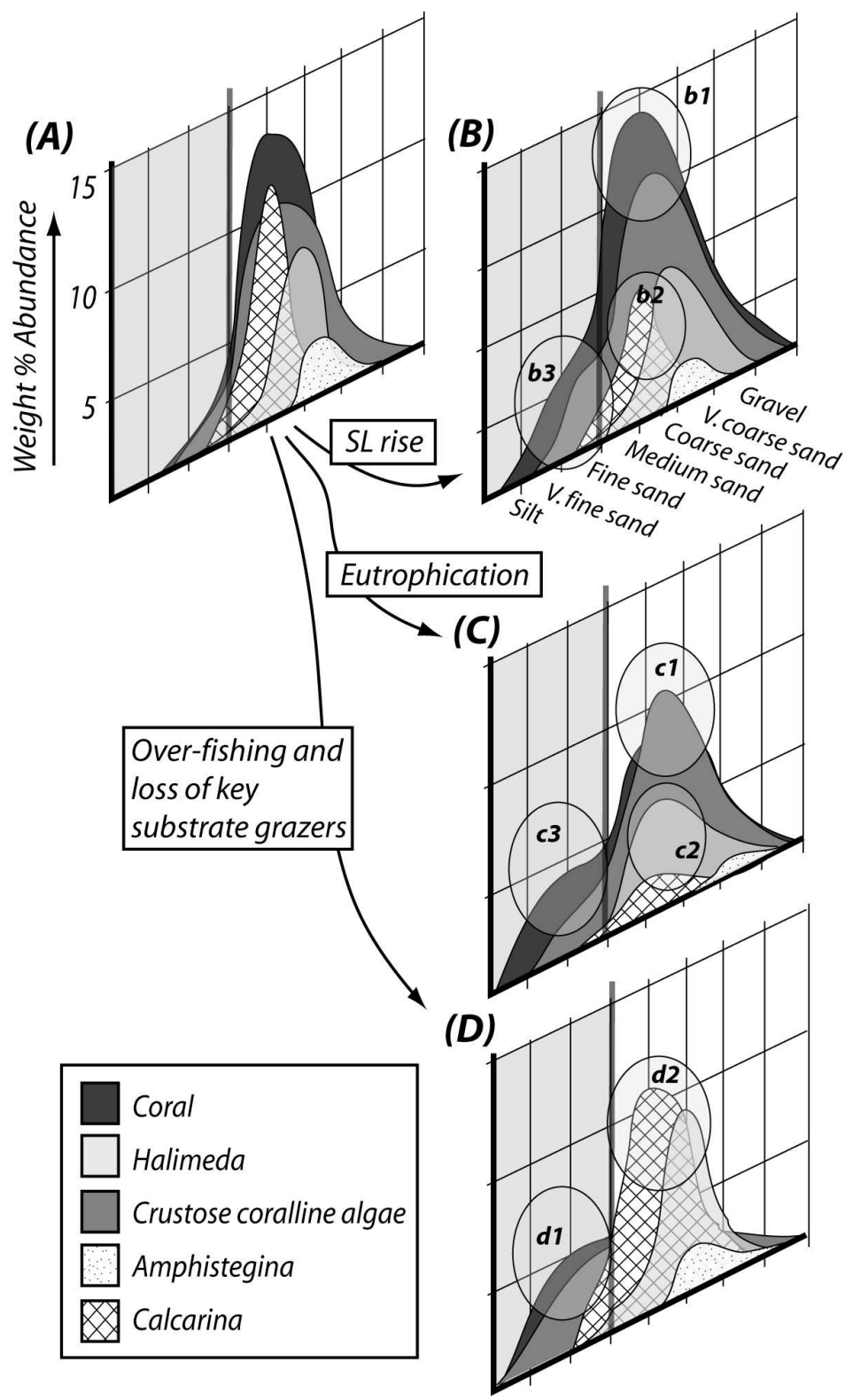

Fig. 9 Conceptual modelled examples of the effects of ecological change on reef flat sediment production: Path $A$ to $B$ is driven by sea-level rise; Path $A$ to $C$ by eutrophication; and Path $A$ to $D$ by over-fishing (see text for explanation). The grain size threshold point below which sediment is unlikely to be of suitable size for island construction is shown with the grey vertical line and grey boxed zone.

$101 \times 168 \mathrm{~mm}(300 \times 300 \mathrm{DPI})$ 


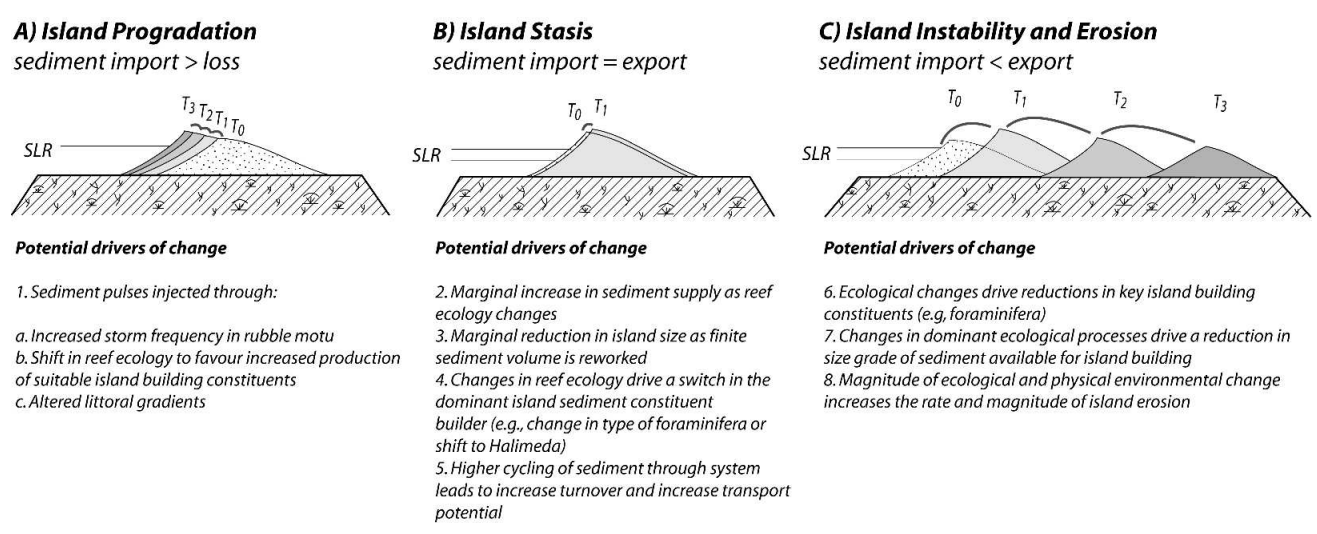

Fig. 10 Projected styles of island morphological responses to sea level change and altered sediment supply regimes, many of which can occur as a response to ecological change (see Table 1). T0

represents current island morphology T1-T3 represent future morphological trajectories of islands. A simplified island morphology has been selected to demonstrate the range of responses.

$275 \times 107 \mathrm{~mm}(300 \times 300$ DPI $)$ 